\title{
Proteomics analysis of differentially expressed proteins in chicken trachea and kidney after infection with the highly virulent and attenuated coronavirus infectious bronchitis virus in vivo
}

\author{
Zhongzan Cao ${ }^{1,2}$, Zongxi Han', Yuhao Shao', Xiaoli Liu', Junfeng Sun', Demin Yu', Xiangang Kong ${ }^{1}$ and
} Shengwang Liu $^{1 *}$

\begin{abstract}
Background: Infectious bronchitis virus (IBV) is first to be discovered coronavirus which is probably endemic in all regions with intensive impact on poultry production. In this study, we used two-dimensional gel electrophoresis (2DE) and two-dimensional fluorescence difference gel electrophoresis (2-DIGE), coupled with matrix-assisted laser desorption/ionization time-of-flight tandem mass spectrometry (MALDI-TOF/TOF-MS), to explore the global proteome profiles of trachea and kidney tissues from chicken at different stages infected in vivo with the highly virulent $\mathrm{ck} / \mathrm{CH} / \mathrm{LDL} / 97 \mathrm{P} \mathrm{P}_{5}$ strain of infectious bronchitis virus (IBV) and the embryo-passaged, attenuated ck/CH/ LDL/97I $P_{115}$ strain.
\end{abstract}

Results: Fifty-eight differentially expressed proteins were identified. Results demonstrated that some proteins which had functions in cytoskeleton organization, anti-oxidative stress, and stress response, showed different change patterns in abundance from chicken infected with the highly virulent $\mathrm{Ck} / \mathrm{CH} / \mathrm{LDL} / 97 \mathrm{I} \mathrm{P}_{5}$ strain and those given the embryo-passaged, attenuated $P_{115}$ stain. In addition, the dynamic transcriptional alterations of 12 selected proteins were analyzed by the real-time RT-PCR, and western blot analysis confirmed the change in abundance of heat shock proteins (HSP) beta-1, annexin A2, and annexin A5.

Conclusions: The proteomic alterations described here may suggest that these changes to protein expression correlate with IBV virus' virulence in chicken, hence provides valuable insights into the interactions of IBV with its host and may also assist with investigations of the pathogenesis of IBV and other coronavirus infections.

Keywords: Infectious bronchitis virus, Proteomics, Chicken, Trachea, Kidney

\section{Background}

Coronaviruses (CoVs) are enveloped single-stranded positive sense RNA viruses that belong to the family Coronaviridae in the order Nidovirales. They are able to infect humans as well as other animals, including cows, pigs, mice, and chickens, they generally cause respiratory infection, gastrointestinal, and neurological disorders of varying severity. Infectious bronchitis virus (IBV) was

\footnotetext{
* Correspondence: swliu@hvri.ac.cn

'Division of Avian Infectious Diseases, State Key Laboratory of Veterinary Biotechnology, Harbin Veterinary Research Institute, the Chinese Academy of Agricultural Sciences, Harbin 150001, People's Republic of China Full list of author information is available at the end of the article
}

the first coronavirus to be discovered, and is classed among the Gamma coronaviruses on the basis of antigenic and genetic relatedness [1]. It is a major poultry pathogen and is probably endemic in all chicken-raising regions; it has a severe impact on poultry production, causing heavy economic losses. All strains of IBV are capable of infecting a large range of epithelial surfaces of chickens, such as those of the trachea, kidney, oviduct and proventriculus [2].

Coronavirus infection has dramatic effects on host cell morphology, transcription and translation patterns, the cell cycle, cytoskeleton, suppression of interferon, and apoptosis pathways. Coronavirus infection may also 
cause inflammation, alter the immune and stress responses, and modify the coagulation pathways [3]. Such profound functional and morphological changes in host cells are associated with significant changes in the patterns of expression of host cell genes. Several studies have described changes in host gene expression associated with coronavirus infection, as documented by microarray technologies [4-9]. But ultimately, protein expression and post-translational modification (PTM) determine virus replication. Furthermore, transcriptome analyses only provide a snapshot of gene expression patterns; they also suffer from several limitations, including inconsistencies with the levels of expression of the corresponding proteins as well as lacking the ability to provide information on PTM. Approaches that use proteomics are promising because they can circumvent some of the issues associated with transcriptomics approaches [10]. More recently, comparative proteomics analysis has emerged as a valuable tool for the establishment of the global host protein profile in response to virus infection. It has been used to study enveloped RNA viruses such as influenza virus, respiratory syncytial virus (RSV), parainfluenza virus (PIV), human metapneumovirus (hMPV), SARS-CoV, and mouse hepatitis virus (MHV) [11-18]. It provides invaluable information on the cellular signaling pathways involved in either the cellular response to viral infections, or the viral manipulation of cellular machinery to ensure their own survival. For IBV, to the best of our knowledge, only some recent studies have investigated the changes in the expression of cellular proteins during IBV infection in ex vivo or in ovo [19-21]. However, the in vivo infection model could yield more biologically relevant insights into pathogenesis.

In this study, we used two-dimensional gel electrophoresis (2-DE) and two-dimensional fluorescence difference gel electrophoresis (2-DIGE), coupled with matrix-assisted laser desorption/ionization time-of-flight tandem mass spectrometry (MALDI-TOF/TOF-MS), to explore global changed proteome profiles of trachea and kidney tissues from chicken at different stages infected in vivo with the highly virulent $\mathrm{ck} / \mathrm{CH} / \mathrm{LDL} / 97 \mathrm{I} \mathrm{P}_{5}$ strain of IBV and an embryo-passaged strain of attenuated virulence, $\mathrm{ck} / \mathrm{CH} / \mathrm{LDL} / 97 \mathrm{I} \mathrm{P}_{115}$. In total, 58 differentially expressed proteins were identified and classified into several functional categories, including cytoskeleton organization, anti-oxidative stress, the stress response, acute phase response, and energy metabolism. In addition, the dynamic transcriptional alterations of 12 selected proteins were analyzed by the real-time RTPCR method. Simultaneously, western blot analysis confirmed the change in abundance of the heat shock proteins (HSP) beta-1, annexin A2, and annexin A5. The potential roles of some of these identified proteins are discussed in order to characterize their potential functional roles during IBV infection in vivo. These results provide valuable insights into the interactions of IBV with its host, and may also be useful in investigations of the pathogenesis of IBV and other coronaviruses.

\section{Results}

\section{IBV antibody detection and observed clinical signs}

All chickens exhibited respiratory clinical signs at about 4-14 dpi with the IBV ck/CH/LDL/97I $\mathrm{P}_{5}$ strain. The clinical signs included tracheal rales, watery eyes, nasal mucus, and sneezing. The clinical signs shown by the inoculated birds tended to disappear gradually after 14 dpi. Gross lesions of the chickens killed in the $\mathrm{P}_{5}$ infected group were confined mainly to the kidneys. The kidney parenchyma of the dead birds was pale, swollen and mottled; the tubules and urethras were distended with uric acid crystals [22]. For chickens in the control group and those inoculated with the IBV ck/CH/LDL/ 97I $\mathrm{P}_{115}$ strain, no respiratory clinical signs and no gross lesions were observed during the experimental period.

As summarized in Additional file 1, no chickens inoculated with the $\mathrm{ck} / \mathrm{CH} / \mathrm{LDL} / 97 \mathrm{I} \mathrm{P}_{5}$ or the $\mathrm{ck} / \mathrm{CH} /$ LDL/97I $\mathrm{P}_{115}$ strain of IBV showed seroconversion at 4 dpi. Antibodies appeared at $7 \mathrm{dpi}$ and all of the chickens showed seroconversion after $14 \mathrm{dpi}$ with both IBV strains. The chickens in the non-inoculated control group showed a negative serum antibody response.

\section{Analysis of viral load in the trachea and kidney of IBV- infected chickens}

Successful IBV infection was also verified using realtime RT-PCR. Results are presented in Figure 1. Virus was not detected from the trachea and kidney of chickens from control group. In the $\mathrm{P}_{5}$-infected group, virus was detected from trachea and kidney at 4, 7, 14, and $21 \mathrm{dpi}$, the peak of viral copy number was reached at 4 $\mathrm{dpi}$, after which time viral load fell. In trachea of $\mathrm{P}_{115^{-}}$ infected group, the peak of viral copy number was at 4 $\mathrm{dpi}$, then fell until $14 \mathrm{dpi}$, and a little fluctuated at 21 dpi. In kidney of $\mathrm{P}_{115}$-infected group, the peak of viral copy number was also at $4 \mathrm{dpi}$, then fell at $7 \mathrm{dpi}$, and only a little fluctuated at 14 and $21 \mathrm{dpi}$. Furthermore, both in trachea and kidney, the $\mathrm{P}_{115}$-infected group had the lower viral genome copies than $\mathrm{P}_{5}$-infected group.

\section{Analysis of differentially changed proteins in abundance by 2-DE and 2-DIGE}

The global protein changes in the chicken trachea and kidney tissues at different stages after infection with the IBV $\mathrm{ck} / \mathrm{CH} / \mathrm{LDL} / 97 \mathrm{I} \mathrm{P}_{5}$ and ck/CH/LDL/97I $\mathrm{P}_{115}$ strain were investigated. For the tracheal protein samples, Figure 2 shows representative images of the tracheal samples: 1366 $\pm 39,1536 \pm 126$, and $1600 \pm 167$ protein spots were 


\section{A. Trachea}

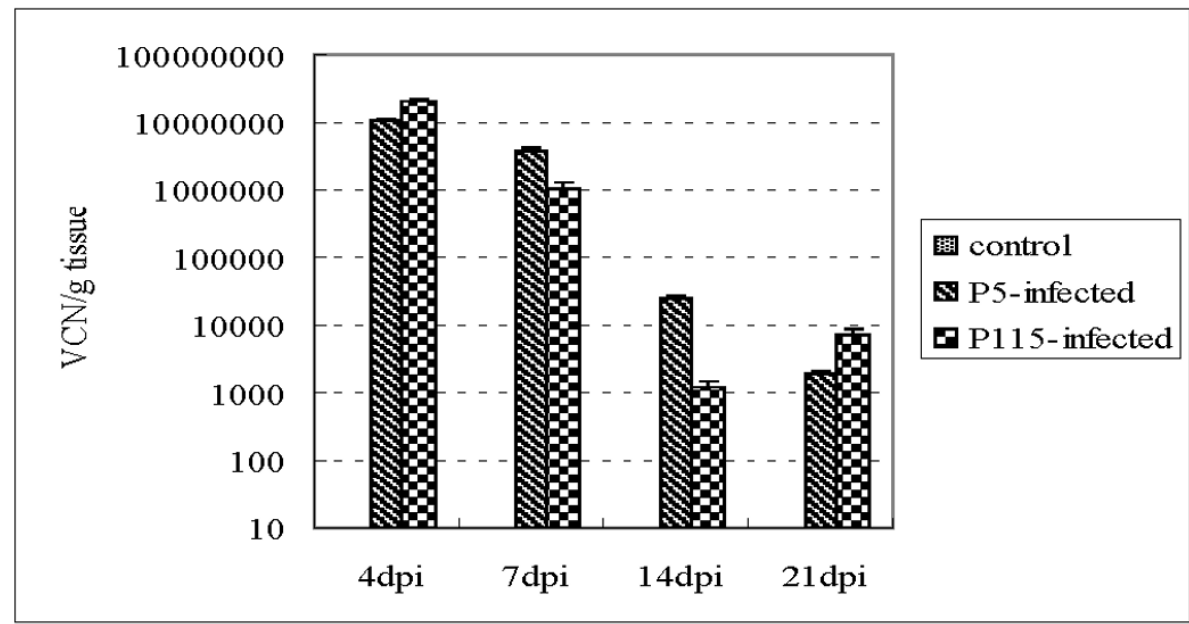

\section{B. Kidney}

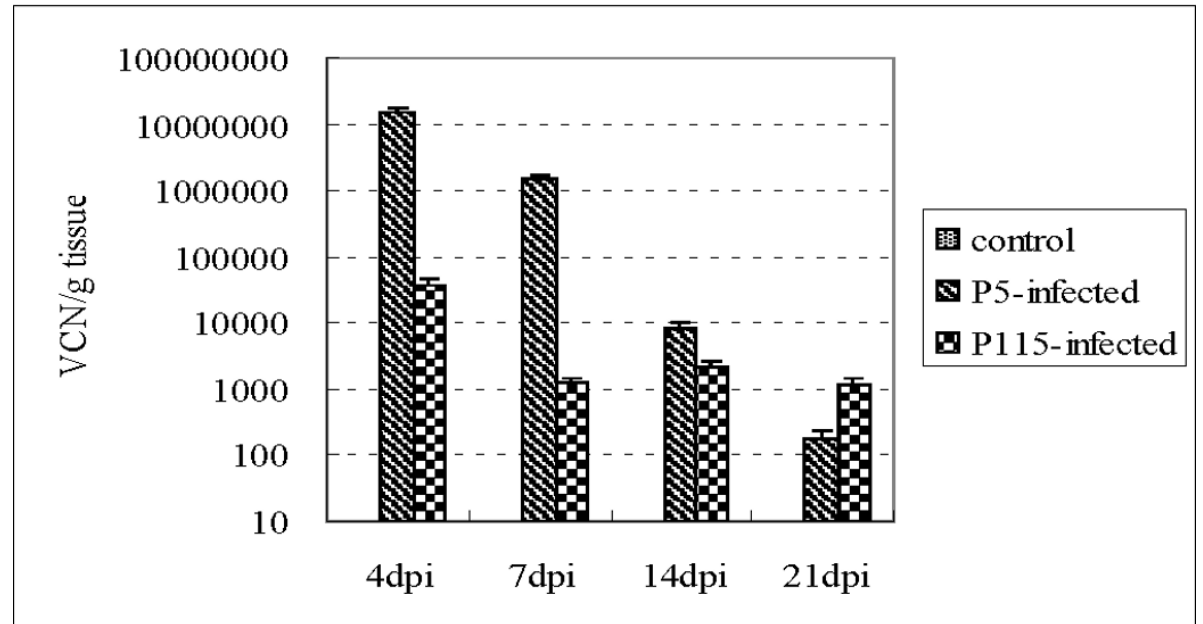

Figure 1 The viral load in each sample was quantified using real-time RT-PCR. The average viral copy number (VCN) per $g$ tissue of each group was calculated. Error bars indicate standard error of the mean, and dpi represent days post-inoculation.

detected in gels from the control group, $\mathrm{P}_{5}$-infected group, and $\mathrm{P}_{115}$-infected group at $4 \mathrm{dpi} ; 1355 \pm 300,1518 \pm 175$, and $1078 \pm 122$ protein spots were detected in gels from the control group, $\mathrm{P}_{5}$-infected group, and $\mathrm{P}_{115}$-infected group at $7 \mathrm{dpi} ; 1293 \pm 91,1365 \pm 126$, and $1220 \pm 56$ protein spots were detected in gels from the control group, $\mathrm{P}_{5}$-infected group, and $\mathrm{P}_{115}$-infected group at $14 \mathrm{dpi} ; 1204$ $\pm 91,1236 \pm 42$, and $1111 \pm 50$ protein spots were detected in gels from the control group, $\mathrm{P}_{5}$-infected group, and $\mathrm{P}_{115}$-infected group at $21 \mathrm{dpi}$. For the kidney protein samples, Figure 3 shows representative images of the kidney samples at 4, 7, 14, and 21 dpi: $2315 \pm 87,2482 \pm 189$, $2607 \pm 238$, and $2593 \pm 192$ protein spots were detected, respectively.

The number of differentially expressed protein spots in the $\mathrm{P}_{5}$ and $\mathrm{P}_{115}$ infected groups is summarized in
Additional file 2. In the tracheal total proteome at $4 \mathrm{dpi}$, the host response to infection with both $\mathrm{P}_{5}$ and $\mathrm{P}_{115}$ strains appears to involve predominantly increase of proteins abundance. By $7 \mathrm{dpi}$, the pattern is different, with infection with the $\mathrm{P}_{115}$ strain resulting in a predominant increase of proteins abundance, and with $\mathrm{P}_{5}$ exhibiting a majority of decrease events. By 14 and 21 $\mathrm{dpi}$, both viruses produce a broadly similar response, with the vast majority of changes in protein abundance involving increase. For the kidney total proteome, at 4 dpi, $P_{5}$ infection induced an approximately equivalent number of proteins with increased and decreased abundance, whereas $P_{115}$ infection induced mainly increase of proteins abundance. By 7, 14, and 21 dpi, both $P_{5}$ and $\mathrm{P}_{115}$ infection induced mainly increase of host proteins abundance. 


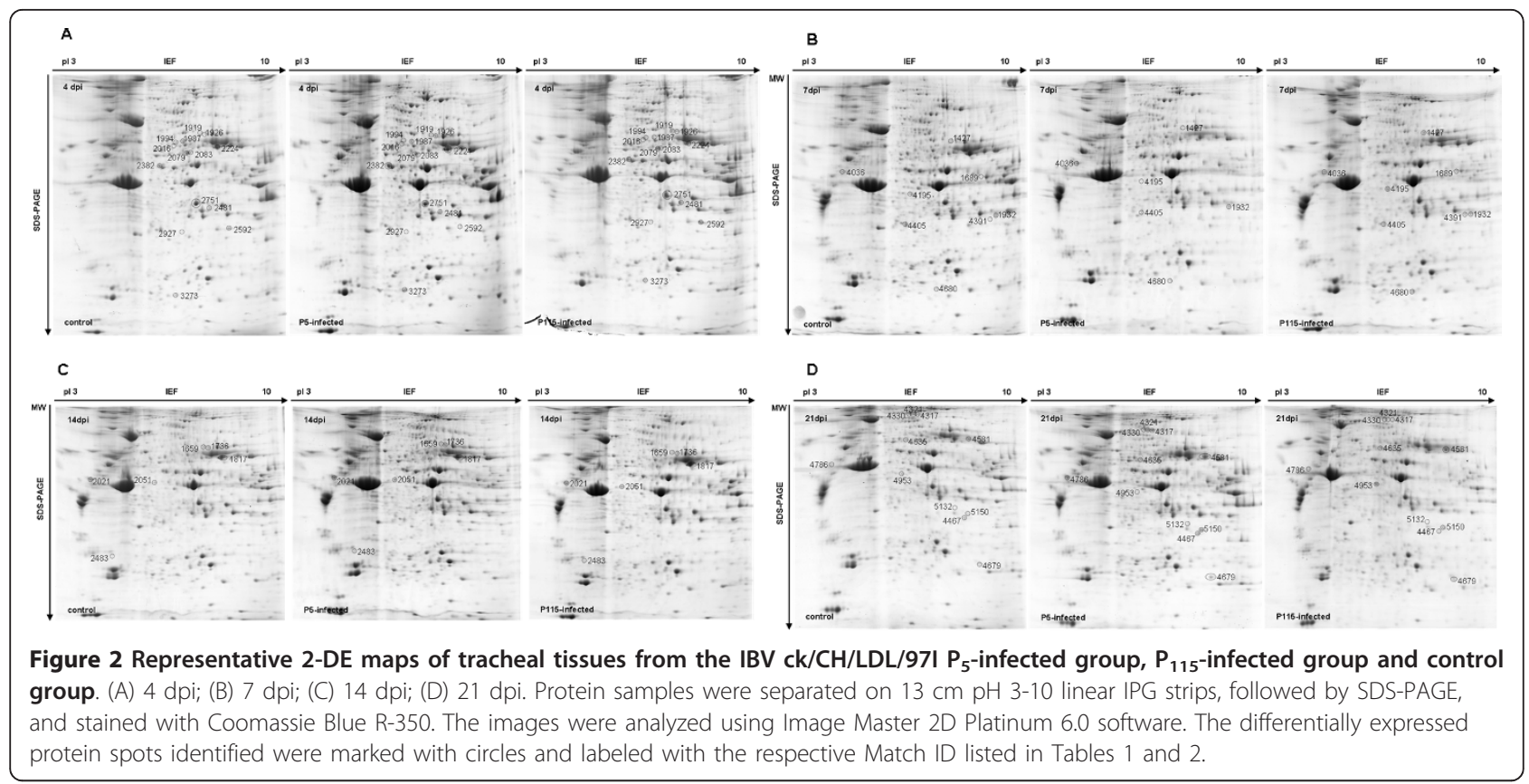

\section{Identification of differentially changed proteins in} abundance by MS

All interesting changed protein spots in trachea and kidney tissues were excised, and identified by MALDI-
TOF-TOF MS. From trachea and kidney tissues, 24 and 34 proteins were successfully identified, respectively. Detailed information on the identified proteins is provided in Tables 1, 2, 3 and 4, Additional file 3, and

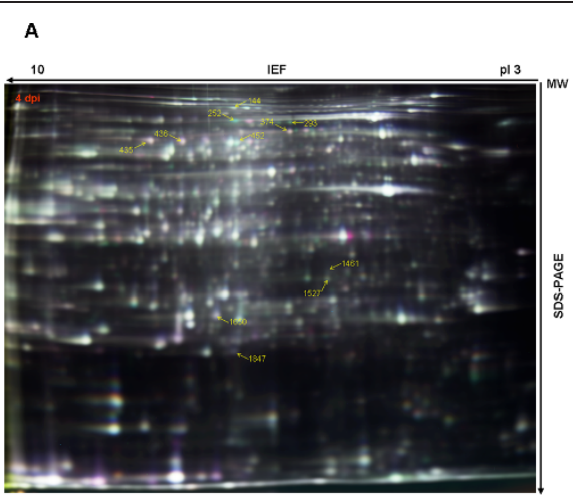

C

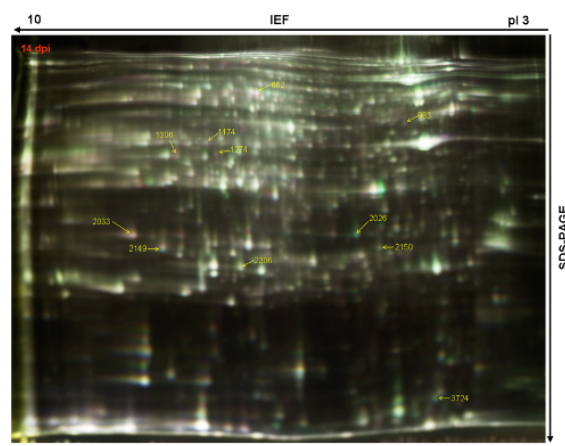

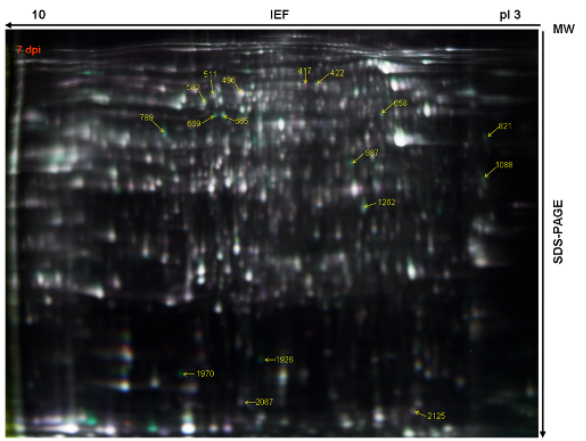

D

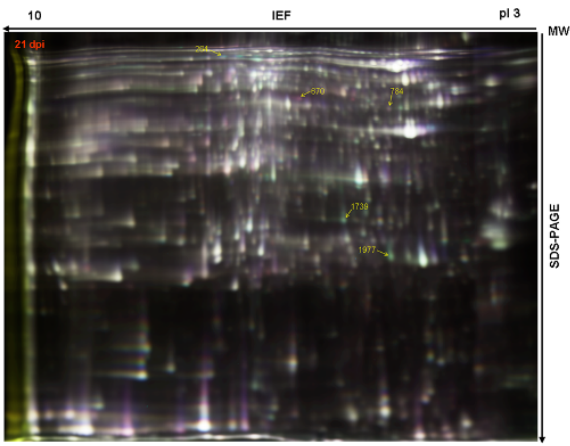

Figure 3 Representative 2-DIGE maps of kidney tissues from the IBV ck/CH/LDL/97I $P_{5}$-infected group, $P_{115}$-infected group and control group. (A) 4 dpi; (B) 7 dpi; (C) 14 dpi; (D) 21 dpi. Protein samples labeled with fluor were separated on 24 cm pH 3-10 linear IPG strips, followed by SDS-PAGE, gels were scanned on a Typhoon 9400 scanner, and image analysis was performed with Ettan ${ }^{\mathbf{T M}}$ DeCyder Software version v6.5. The protein spots identified were marked with circles and labeled with the respective Match ID listed in Tables 3 and 4. 
Table 1 Similar abundance changed proteins in tracheal from chicken infected with IBV ck/CH/LDL/97I $\mathbf{P}_{\mathbf{5}}$ and $\mathrm{ck} / \mathrm{CH} / \mathrm{LDL} / \mathbf{9 7} \mathrm{P}_{\mathbf{1 1 5}}$

Match Protein description Accession Protein Protein $\mathrm{Mw} \quad \mathrm{pl}$ Average ratio and $p$-value

\begin{tabular}{|c|c|c|c|c|c|c|c|c|c|c|c|c|c|c|c|c|c|c|c|c|c|c|}
\hline \multirow[t]{4}{*}{ 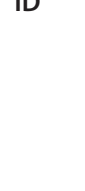 } & & & \multirow[t]{4}{*}{ sevic } & \multirow[t]{4}{*}{$\%^{\mathrm{c}}$} & \multirow[t]{4}{*}{ (10) } & & & & & & & & & & & & & & & & & \\
\hline & & & & & & & \multicolumn{8}{|c|}{$P_{5}$-infected/control } & \multicolumn{8}{|c|}{$\mathrm{P}_{115}$-infected/control } \\
\hline & & & & & & & \multicolumn{2}{|c|}{$4 \mathrm{dpi}$} & \multicolumn{2}{|c|}{$7 \mathrm{dpi}$} & \multicolumn{2}{|c|}{$14 \mathrm{dpi}$} & \multicolumn{2}{|c|}{$21 \mathrm{dpi}$} & \multicolumn{2}{|c|}{$4 \mathrm{dpi}$} & \multicolumn{2}{|c|}{$7 \mathrm{dpi}$} & \multicolumn{2}{|c|}{14 dpi } & \multicolumn{2}{|c|}{$21 \mathrm{dpi}$} \\
\hline & & & & & & & ratio & $p$ & ratio & $p$ & ratio & $p$ & ratio & $p$ & ratio & $p$ & ratio & $p$ & ratio & $p$ & ratio & $p$ \\
\hline 4467 & annexin A1 (ANXA1) & $\begin{array}{l}\text { gil } \\
46195459\end{array}$ & 910 & 100 & 38761 & 7.05 & & & & & & & 0.89 & 0.435 & & & & & & & 0.49 & 0.001 \\
\hline 2051 & B-creatine kinase & gi|211235 & 631 & 100 & 42525.5 & 5.78 & & & & & 1.44 & 0.025 & & & & & & & 1.77 & 0.006 & & \\
\hline $\begin{array}{l}1926, \\
1736, \\
1817, \\
4581\end{array}$ & $\begin{array}{l}\text { cartilage matrix protein } \\
\text { precursor }\end{array}$ & $\begin{array}{l}\text { gil } \\
71896317\end{array}$ & 314 & 100 & 54798.1 & 6.63 & 2.71 & 0.006 & & & 1.24 & 0.427 & 1.94 & 0.003 & 2.48 & 0.025 & & & 1.96 & 0.012 & 2.46 & 0 \\
\hline 1987 & fibrinogen beta chain & gi|211780 & 612 & 100 & 53271.8 & 7.18 & 2.75 & 0.006 & & & & & & & 2.57 & 0.011 & & & & & & \\
\hline 4679 & $\begin{array}{l}\text { glutathione S-transferase } \\
\text { class-alpha }\end{array}$ & gi|4959550 & 79 & 99.958 & 21326.5 & 8.03 & & & & & & & 1.36 & 0.005 & & & & & & & 1.8 & 0 \\
\hline 4036 & $\begin{array}{l}\text { keratin, type I cytoskeletal } \\
19\end{array}$ & $\begin{array}{l}\text { gi| } \\
45384356\end{array}$ & 772 & 100 & 46111 & 4.94 & & & 2.43 & 0.016 & & & & & & & 2.15 & 0.009 & & & & \\
\hline 5150 & $\begin{array}{l}\text { nmrA-like family domain- } \\
\text { containing protein } 1\end{array}$ & $\begin{array}{l}\text { gil } \\
71897147\end{array}$ & 653 & 100 & 32726 & 7.77 & & & & & & & 2.21 & 0.004 & & & & & & & 1.72 & 0.009 \\
\hline 4405 & $\begin{array}{l}\text { PREDICTED: microfibril- } \\
\text { associated glycoprotein } 4 \\
\text { (EST) }\end{array}$ & $\begin{array}{l}\text { gil } \\
18470900\end{array}$ & 331 & 100 & 28600 & 5.2 & & & 0.57 & 0.001 & & & & & & & 0.97 & 0.695 & & & & \\
\hline 2021 & Vimentin (VIM) & gi|212868 & 1160 & 100 & 53166.6 & 5.09 & & & & & 0.76 & 0.015 & & & & & & & 0.56 & 0.001 & & \\
\hline
\end{tabular}

a) Match ID represents unique numbers assigned to each spot in the matched standard of ImageMaster 2D Platinum version 6.0 software

b) Accession no. is the MASCOT result of MALDI-TOF/TOF searched from the NCBInr database

c) The criterion for a successfully identified protein is a protein score confidence interval (C.I. \%) for PMF and MS/MS data $\geq 95 \%$ 
Table 2 Differential abundance changed proteins in tracheal from chicken infected with IBV ck/CH/LDL/97I $P_{5}$ and ck/CH/LDL/97I $P_{115}$

Match Protein description Accession Protein Protein $\mathrm{Mw} \quad \mathrm{pl}$ Average ratio and $p$-value

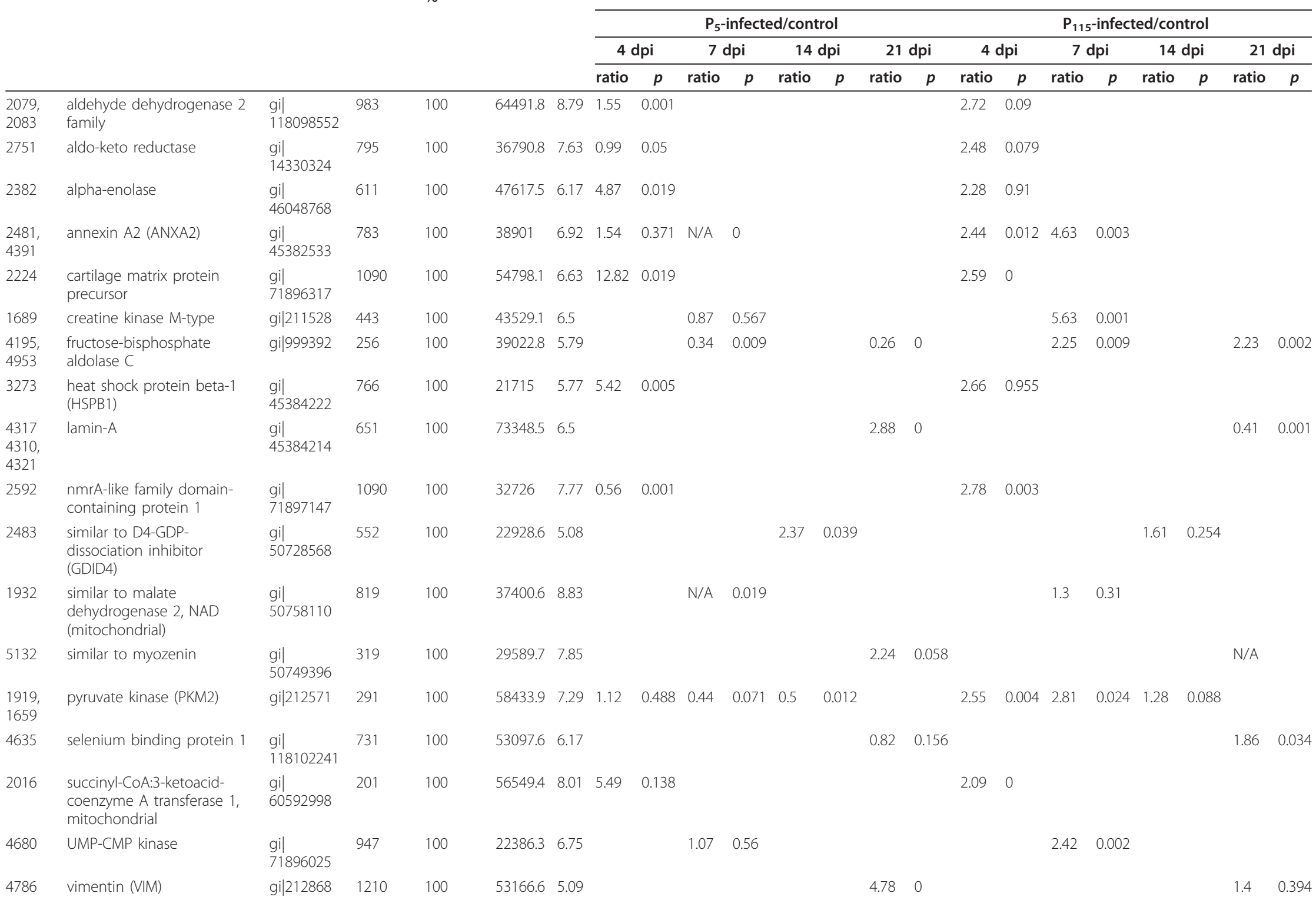

a) Match ID represents unique numbers assigned to each spot in the matched standard of ImageMaster 2D Platinum version 6.0 software

b) Accession no. is the MASCOT result of MALDI-TOF/TOF searched from the NCBInr database

c) The criterion for a successfully identified protein is a protein score confidence interval (C.I. \%) for PMF and MS/MS data $\geq 95 \%$

$\mathrm{N} / \mathrm{A}$ : A indicates the spot was detectable on one of the gels, $\mathrm{N}$ indicates the spot was too weak to detect on one of the gels 
Table 3 Similar abundance changed proteins in kidney from chicken infected with IBV ck/CH/LDL/97I $P_{5}$ and $c k / C H / L D L / 97 / P_{115}$ Master Protein description Accession Protein Protein $\mathrm{Mw} \quad \mathrm{pl}$ Average ratio and $p$-value no. ${ }^{b} \quad$ score score $\mathrm{Cl} \quad(\mathrm{Da})$

\begin{tabular}{|c|c|c|c|c|c|c|c|c|c|c|c|c|c|c|c|c|c|c|c|c|c|c|}
\hline & & & & & & & \multicolumn{8}{|c|}{$P_{5}$-infected/control } & \multicolumn{8}{|c|}{$\mathrm{P}_{115}$-infected/control } \\
\hline & & & & & & & \multicolumn{2}{|c|}{4 dpi } & \multicolumn{2}{|c|}{$7 \mathrm{dpi}$} & \multicolumn{2}{|c|}{$14 \mathrm{dpi}$} & \multicolumn{2}{|c|}{$21 \mathrm{dpi}$} & \multicolumn{2}{|c|}{4 dpi } & \multicolumn{2}{|c|}{$7 \mathrm{dpi}$} & \multicolumn{2}{|c|}{$14 \mathrm{dpi}$} & \multicolumn{2}{|c|}{$21 \mathrm{dpi}$} \\
\hline & & & & & & & ratio & $p$ & ratio & $p$ & ratio & $p$ & ratio & $p$ & ratio & $p$ & ratio & $p$ & ratio & $p$ & ratio & $p$ \\
\hline 2033 & $\begin{array}{l}\text { carbonyl reductase [NADPH] } \\
1\end{array}$ & $\begin{array}{l}\text { gil } \\
71895267\end{array}$ & 1110 & 100 & 30519.9 & 8.5 & & & & & & & & & & & & & 1.66 & 0.005 & & \\
\hline 435 & catalase & $\begin{array}{l}\text { gil } \\
53127216\end{array}$ & 529 & 100 & 60279 & 8.09 & 0.64 & 0.002 & & & & & & & 0.67 & 0 & & & & & & \\
\hline $\begin{array}{l}252 \\
264\end{array}$ & $\begin{array}{l}\text { chain } A \text {, the structure of } \\
\text { chicken mitochondrial Pepck } \\
\text { in complex with Pep (PCK2) }\end{array}$ & $\begin{array}{l}\text { gi| } \\
158430534\end{array}$ & 989 & 100 & 68009.9 & 6.55 & 4.27 & 0.015 & & & & & & & 3.6 & 0.019 & & & & & 1.56 & 0.038 \\
\hline $\begin{array}{l}2125 \\
3724\end{array}$ & chain $\mathrm{A}$, transthyretin & gi|1633502 & 672 & 100 & 14209 & 5.1 & & & 0.63 & 0.005 & 0.99 & 0.88 & & & & & 0.83 & 0.065 & 0.64 & 0 & & \\
\hline 658 & $\begin{array}{l}\text { chain } C \text {, crystal structure of } \\
\text { native chicken fibrinogen } \\
\text { with two different bound } \\
\text { ligands }\end{array}$ & $\begin{array}{l}\text { gil } \\
21730885\end{array}$ & 659 & 100 & 47400.8 & 5.32 & & & 1.71 & 0.039 & & & & & & & 1.68 & 0.022 & & & & \\
\hline 1306 & $\begin{array}{l}\text { class I alcohol } \\
\text { dehydrogenase, beta subunit }\end{array}$ & $\begin{array}{l}\text { gil } \\
45384164\end{array}$ & 286 & 100 & 40891.8 & 7.85 & & & & & 1.49 & 0.001 & & & & & & & 1.54 & 0.001 & & \\
\hline 2087 & $\begin{array}{l}\text { cytochrome c oxidase } \\
\text { subunit } 4 \text { isoform } 1 \\
\text { mitochondrial }\end{array}$ & $\begin{array}{l}\text { gi| } \\
71895513\end{array}$ & 359 & 100 & 19676.1 & 8.91 & & & 0.58 & 0.008 & & & & & & & 0.57 & 0.026 & & & & \\
\hline 1274 & D-amino-acid oxidase & $\begin{array}{l}\text { gi| } \\
118098567\end{array}$ & 298 & 100 & 41209.8 & 6.7 & & & & & 1.4 & 0.15 & & & & & & & 1.55 & 0.001 & & \\
\hline 144 & ovotransferrin BB type & $\begin{array}{l}\text { gi| } \\
71274075\end{array}$ & 1020 & 100 & 79606.1 & 6.85 & 1.3 & 0.003 & & & & & & & 1.56 & 0 & & & & & & \\
\hline 374 & $\begin{array}{l}\text { similar to CDNA sequence } \\
\text { BC048390 }\end{array}$ & $\begin{array}{l}\text { gi| } \\
118098312\end{array}$ & 1030 & 100 & 65576.4 & 7.85 & 0.64 & 0.001 & & & & & & & 0.60 & 0 & & & & & & \\
\hline 417 & $\begin{array}{l}\text { similar to CDNA sequence } \\
\text { BC048390 }\end{array}$ & $\begin{array}{l}\text { gi| } \\
118098312\end{array}$ & 734 & 100 & 65576.4 & 7.85 & & & 0.52 & 0.008 & & & & & & & 0.81 & 0.13 & & & & \\
\hline 422 & $\begin{array}{l}\text { similar to CDNA sequence } \\
\text { BC048391 }\end{array}$ & $\begin{array}{l}\text { gi| } \\
118098312\end{array}$ & 865 & 100 & 65576.4 & 7.85 & & & 1.35 & 0.033 & & & & & & & 1.52 & 0.021 & & & & \\
\hline 436 & similar to cystathionase & $\begin{array}{l}\text { gil } \\
118094764\end{array}$ & 618 & 100 & 44554.7 & 6.86 & 0.78 & 0.032 & & & & & & & 0.66 & 0.001 & & & & & & \\
\hline 2149 & $\begin{array}{l}\text { similar to dodecenoyl- } \\
\text { coenzyme A delta isomerase } \\
\text { (3,2 trans-enoyl-coenzyme A } \\
\text { isomerase) }\end{array}$ & $\begin{array}{l}\text { gi| } \\
118098151\end{array}$ & 502 & 100 & 34557.8 & 9.3 & & & & & 1.63 & 0.003 & & & & & & & 1.19 & 0.023 & & \\
\hline 670 & similar to FLJ20699 protein & $\begin{array}{l}\text { gi| } \\
118083181\end{array}$ & 352 & 100 & 52820.8 & 5.95 & & & & & & & 0.75 & 0.006 & & & & & & & 0.5 & 0 \\
\hline
\end{tabular}


Table 3 Similar abundance changed proteins in kidney from chicken infected with IBV ck/CH/LDL/97I $\mathbf{P}_{5}$ and $\mathbf{c k} / \mathrm{CH}_{\mathbf{L}} \mathrm{LDL} / \mathbf{9 7 |} \mathbf{P}_{\mathbf{1 1 5}}$ (Continued)

\begin{tabular}{|c|c|c|c|c|c|c|c|c|c|c|c|c|c|c|c|c|c|c|c|c|}
\hline $\begin{array}{l}1527, \\
2150\end{array}$ & $\begin{array}{l}\text { similar to guanidinoacetate } \\
\mathrm{N} \text {-methyltransferase }\end{array}$ & $\begin{array}{l}\text { gil } \\
118103242\end{array}$ & 424 & 100 & 17457.7 & 6.59 & 0.63 & 0 & & & 0.65 & 0.001 & & 0.73 & 0.001 & & & 0.86 & 0.002 & \\
\hline 1174 & receptor-associated protein & gi|2661436 & 440 & 100 & 40792.2 & 8.61 & & & & & 1.66 & 0.032 & & & & & & 1.28 & 0.11 & \\
\hline 511 & retinal dehydrogenase 1 & $\begin{array}{l}\text { gi| } \\
45383031\end{array}$ & 534 & 100 & 56400.8 & 7.49 & & & 1.26 & 0.096 & & & & & & 1.57 & 0.013 & & & \\
\hline 1739 & $\begin{array}{l}\text { similar to methyltransferase } \\
24\end{array}$ & $\begin{array}{l}\text { gil } \\
50750103\end{array}$ & 614 & 100 & 30640.5 & 6 & & & & & & 1.65 & 0 & & & & & & 1.87 & 0 \\
\hline
\end{tabular}

a) Match ID represents unique numbers assigned to each spot in the matched standard of Ettan ${ }^{\mathrm{TM}}$ DeCyder 2D v6.5 software

b) Accession no. is the MASCOT result of MALDI-TOF/TOF searched from the NCBInr database

c) The criterion for successful identification of a protein is a protein score confidence interval (C.I. \%) for PMF and MS/MS data $\geq 95 \%$ 
Table 4 Differential abundance changed proteins in kidney from chicken infected with IBV ck/CH/LDL/97I $P_{5}$ and $c k / C H / L D L / 97 \mid P_{115}$

\begin{tabular}{|c|c|c|c|c|c|c|c|c|c|c|c|c|c|c|c|c|c|c|c|c|c|c|}
\hline \multirow{4}{*}{$\begin{array}{l}\text { Master } \\
\text { ID }^{\mathrm{a}}\end{array}$} & \multirow[t]{4}{*}{ Protein description } & \multirow{4}{*}{$\begin{array}{l}\text { Accession } \\
\text { no. }{ }^{\text {b }}\end{array}$} & \multirow{4}{*}{$\begin{array}{l}\text { Protein } \\
\text { score }\end{array}$} & \multirow{4}{*}{$\begin{array}{l}\text { Protein } \\
\text { score } \mathrm{Cl} \\
\%^{\mathrm{c}}\end{array}$} & \multirow{4}{*}{$\begin{array}{l}\mathrm{Mw} \\
(\mathrm{Da})\end{array}$} & \multirow[t]{4}{*}{$\mathrm{pl}$} & \multicolumn{16}{|c|}{ Average ratio and $p$-value } \\
\hline & & & & & & & \multicolumn{8}{|c|}{$P_{5}$-infected/control } & \multicolumn{8}{|c|}{$P_{115}$-infected/control } \\
\hline & & & & & & & \multicolumn{2}{|c|}{$4 \mathrm{dpi}$} & \multicolumn{2}{|c|}{$7 \mathrm{dpi}$} & \multicolumn{2}{|c|}{$14 \mathrm{dpi}$} & \multicolumn{2}{|c|}{$21 \mathrm{dpi}$} & \multicolumn{2}{|c|}{$4 \mathrm{dpi}$} & \multicolumn{2}{|c|}{$7 \mathrm{dpi}$} & \multicolumn{2}{|c|}{$14 \mathrm{dpi}$} & \multicolumn{2}{|c|}{$21 \mathrm{dpi}$} \\
\hline & & & & & & & ratio & $p$ & ratio & $p$ & ratio & $p$ & ratio & $p$ & ratio & $p$ & ratio & $p$ & ratio & $p$ & ratio & $p$ \\
\hline 496 & $\begin{array}{l}\text { aldehyde dehydrogenase } 4 \\
\text { family, member A1 }\end{array}$ & $\begin{array}{l}\text { gi| } \\
118101121\end{array}$ & 1010 & 100 & 112936 & 5.4 & & & 0.56 & 0.009 & & & & & & & 0.85 & 0.031 & & & & \\
\hline 662 & $\begin{array}{l}\text { aldehyde dehydrogenase } 4 \\
\text { family, member } A 1\end{array}$ & $\begin{array}{l}\text { gi| } \\
118101121\end{array}$ & 890 & 100 & 112936 & 5.4 & & & & & 1.03 & 0.84 & & & & & & & 1.59 & 0.015 & & \\
\hline 452 & alpha-enolase & $\begin{array}{l}\text { gi| } \\
46048768\end{array}$ & 353 & 100 & 47617.5 & 6.17 & 1.25 & 0.14 & & & & & & & 1.7 & 0.003 & & & & & & \\
\hline $\begin{array}{l}821 \\
1088\end{array}$ & $\begin{array}{l}\text { alpha-tropomyosin of } \\
\text { smooth muscle (TPM1) }\end{array}$ & gi|833618 & 94 & 99.999 & 32962.7 & 4.67 & & & 2.22 & 0.003 & & & & & & & 1.16 & 0.46 & & & & \\
\hline 1977 & apolipoprotein A-I (APOA1) & gi|211159 & 703 & 100 & 30673.2 & 5.58 & & & & & & & 0.97 & 0.31 & & & & & & & 1.58 & 0 \\
\hline 1262 & $\begin{array}{l}\text { chain } \mathrm{A} \text {, crystal structures of } \\
\text { chicken annexin } \mathrm{V} \text { in } \\
\text { complex with } \mathrm{Ca}^{2+} \text { (ANXA5) }\end{array}$ & $\begin{array}{l}\text { gil } \\
62738641\end{array}$ & 728 & 100 & 36158.6 & 5.61 & & & 2.04 & 0.004 & & & & & & & 1.1 & 0.75 & & & & \\
\hline $\begin{array}{l}983, \\
784\end{array}$ & $\begin{array}{l}\text { chain } C \text {, crystal structure of } \\
\text { native chicken fibrinogen }\end{array}$ & gi|8569623 & 921 & 100 & 47485.9 & 5.4 & & & & & 1.69 & 0.002 & 1.24 & 0.034 & & & & & 1.07 & 0.35 & 0.76 & 0.006 \\
\hline 1926 & $\begin{array}{l}\text { low molecular weight } \\
\text { phosphotyrosine } \\
\text { proteinphosphatase (TCP1) }\end{array}$ & $\begin{array}{l}\text { gil } \\
86129490\end{array}$ & 304 & 100 & 18640.2 & 6.81 & & & 6.34 & 0.045 & & & & & & & 0.74 & 0.16 & & & & \\
\hline 1847 & $\begin{array}{l}\text { manganese-containing } \\
\text { superoxide dismutase } \\
\text { precursor (MNSOD) }\end{array}$ & $\begin{array}{l}\text { gil } \\
12034955\end{array}$ & 258 & 100 & 25158.7 & 8.6 & 1.52 & 0.015 & & & & & & & 1.12 & 0.022 & & & & & & \\
\hline 1970 & $\begin{array}{l}\text { nucleoside diphosphate } \\
\text { kinase }\end{array}$ & gi|2827446 & 445 & 100 & 17542 & 7.11 & & & 4.68 & 0.003 & & & & & & & 1.48 & 0.81 & & & & \\
\hline 293 & $\begin{array}{l}\text { phosphoenolpyruvate } \\
\text { carboxykinase (EC 4.1.1.32) }\end{array}$ & gi|212538 & 492 & 100 & 70224.3 & 6.1 & 1.15 & 0.047 & & & & & & & 1.78 & 0 & & & & & & \\
\hline 665 & $\begin{array}{l}\text { similar to aflatoxin aldehyde } \\
\text { reductase }\end{array}$ & $\begin{array}{l}\text { gil } \\
118101125\end{array}$ & 286 & 100 & 36943.4 & 6.76 & & & 2.61 & 0.004 & & & & & & & 1.28 & 0.059 & & & & \\
\hline 789 & $\begin{array}{l}\text { similar to betaine } \\
\text { homocysteine } \\
\text { methyltransferase }\end{array}$ & $\begin{array}{l}\text { gi| } \\
50755288\end{array}$ & 1010 & 100 & 45552.1 & 7.56 & & & 2.51 & & & & & & & & 1.41 & & & & & \\
\hline 582 & $\begin{array}{l}\text { glutamate dehydrogenase } 1 \text {, } \\
\text { mitochondrial }\end{array}$ & gi|118534 & 339 & 100 & 56075.4 & 8.48 & & & 1.74 & 0.051 & & & & & & & 1.06 & 0.17 & & & & \\
\hline $\begin{array}{l}1461 \\
2026\end{array}$ & $\begin{array}{l}\text { similar to methyltransferase } \\
24 \text { (MET24) }\end{array}$ & $\begin{array}{l}\text { gil } \\
50750103\end{array}$ & 556 & 100 & 30640.5 & 6 & 0.72 & 0.002 & & & 1.25 & 0.074 & & & 1.09 & 0.066 & & & 0.42 & 0 & & \\
\hline 987 & sulfotransferase & $\begin{array}{l}\text { gi| } \\
45384226\end{array}$ & 265 & 100 & 36333.5 & 5.89 & & & 4.53 & 0.01 & & & & & & & 0.98 & 0.85 & & & & \\
\hline 1650 & $\begin{array}{l}\text { triosephosphate isomerase } \\
\text { (EC 5.3.1.1) }\end{array}$ & gi|212774 & 1290 & 100 & 26831.9 & 6.71 & 1.51 & 0.009 & & & & & & & 1.07 & 0.43 & & & & & & \\
\hline
\end{tabular}

a) Match ID represents unique numbers assigned to each spot in the matched standard of Ettan ${ }^{\mathrm{TM}}$ DeCyder 2D v6.5 software

b) Accession no. is the MASCOT result of MALDI-TOF/TOF searched from the NCBInr database

c) The criterion for successful identification of a protein is a protein score confidence interval (C.I. \%) for PMF and MS/MS data $\geq 95 \%$ 
Additional file 4. Figures 2 and 3 show representative gels indicating protein spots identified in tracheal and kidney tissues respectively. As shown in Tables and Figures, several proteins were identified in multiple spots with the same molecular weight but different isoelectric points, such as three spots contained lamin-A (spot \# 4317, 4310, 4321 in Figure 2).

According to annotations from the UniProt Knowledgebase (UniProtKB) and the Gene Ontology databases, most of the identified proteins were involved in cytoskeleton organization, anti-oxidative stress, the stress response, acute phase response, energy metabolism, macromolecular biosynthesis, signal transduction and ion transport (summarized in Additional file 5). Among them, the abundance of annexin A2, annexin A5, pyruvate kinase (PKM2), alpha-enolase, mitochondrial phosphoenolpyruvate carboxykinase (PCK2), triosephosphate isomerase, heat shock protein beta-1, manganese-containing superoxide dismutase (MnSOD), vimentin, lamin-A, cartilage matrix protein, alpha-tropomyosin, nucleoside diphosphate kinase, sulfotransferase, and low molecular weight phosphotyrosine proteinphosphatase, were induced to be differentially patterns changed in chickens infected with the $P_{5}$ and $P_{115}$ strains, suggested that infection with the $P_{5}$ and $P_{115}$ strains produces different host response. Furthermore, this difference in the pattern of change was induced predominantly in the early stages of the infection cycle, which suggests that critical events early in infection are likely to be of key importance in determining the fate of the host. In addition, fibrinogen $\beta$ and $\gamma$ chains showed a similar pattern of change, with increase in the $\mathrm{P}_{5^{-}}$and $\mathrm{P}_{115}$-infected groups.

\section{Gene ontology annotations of differentially changed proteins in abundance}

In order to generate an overview of the subcellular location and biological processes of this abundance changed proteins in trachea and kidney, $\mathrm{P}_{5}$-infected and $\mathrm{P}_{115^{-}}$ infected group, and different dpi, categorization of these proteins was performed on the basis of Gene Ontology (GO) annotations. As shown in Figure 4A, cellular component ontology revealed that the majority of the identified proteins were associated with intracellular (GO:0005622) and cytoplasm (GO:0005737) both in trachea and kidney, $\mathrm{P}_{5}$-infected and $\mathrm{P}_{115}$-infected group, and different dpi. As shown in Figure 4B, biological process ontology revealed that the majority of the identified proteins were associated with metabolic processes (GO:0008152), response to stimulus (GO:0050896), and regulation of biological process (GO:0050789) both in trachea and kidney, $\mathrm{P}_{5}$-infected and $\mathrm{P}_{115}$-infected group, and different dpi.

\section{Analysis of mRNA level by real-time RT-PCR}

The alterations in the mRNA level of 12 selected proteins in the trachea or kidney from the control, $\mathrm{P}_{5}-$
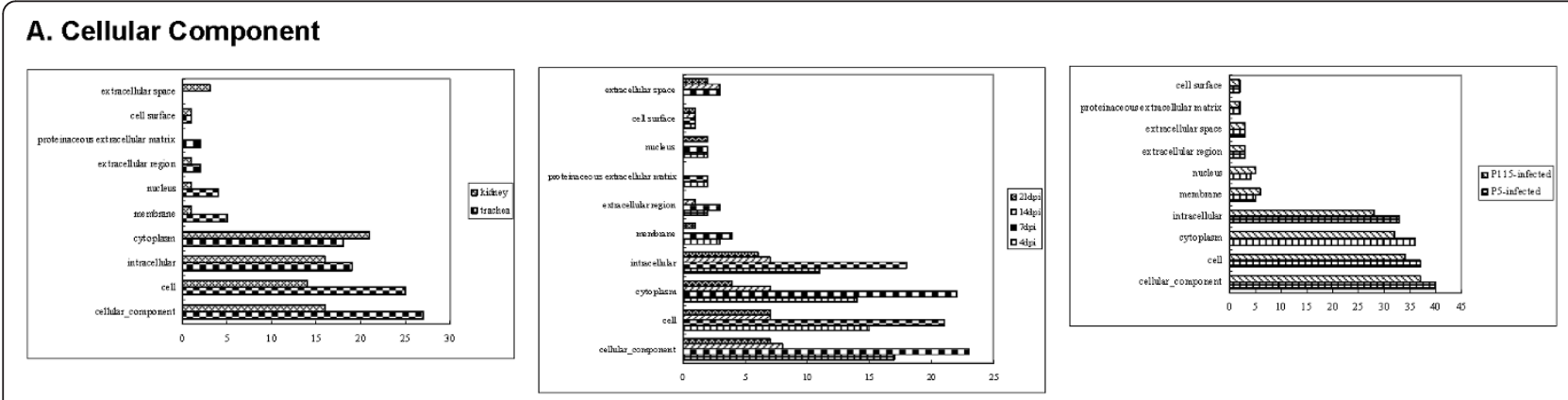

\section{B. Biological Process}
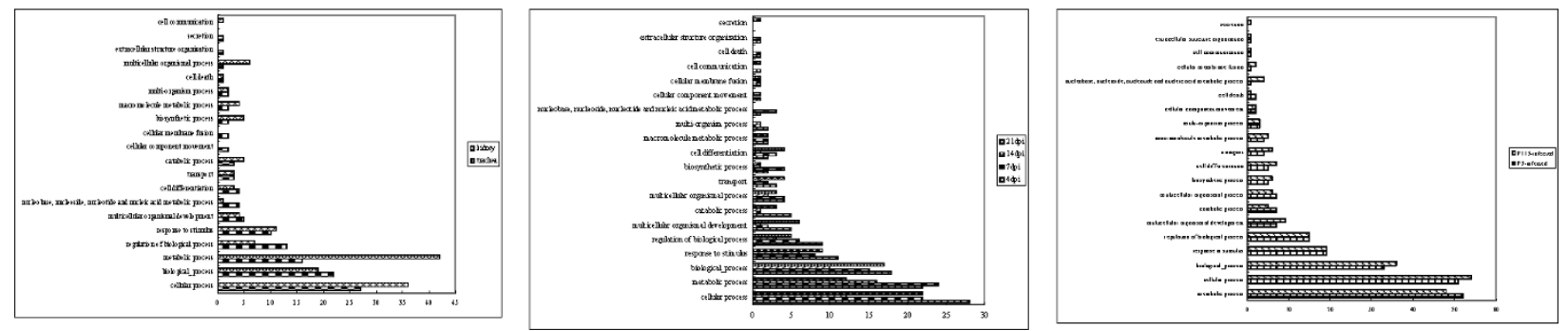

Figure 4 Gene Ontology annotation analysis of differentially expressed proteins according to their cellular component (A) and biological process (B). This classification was produced on the basis of an analysis using the GOSlimViewer tool at the Agbase database http:// www.agbase.msstate.edu/. The results were compared between trachea and kidney, P5-infected and P115-infected group, and different day's post-inoculation. 
infected, and $\mathrm{P}_{115}$-infected groups were analyzed at 4, 7, 14 , and 21 dpi. For genes from tracheal tissue, as shown in Figure 5A, at $4 \mathrm{dpi}$, the mRNA level was up-regulated in the $\mathrm{P}_{5}$-infected group, when compared with the $\mathrm{P}_{115^{-}}$ infected group. By 7 and $14 \mathrm{dpi}$, the majority of the mRNA exhibited similar down-regulation in both the $\mathrm{P}_{5}$-infected group and the $\mathrm{P}_{115}$-infected group. By 21 $\mathrm{dpi}$, their change patterns were different: the mRNA level of these genes was up-regulated in the $\mathrm{P}_{5}$-infected group, but for the $\mathrm{P}_{115}$-infected group, they remained low at this time point. For genes from kidney tissue, as shown in Figure $5 \mathrm{~B}$, at $4 \mathrm{dpi}$, infection with the $\mathrm{P}_{115}$ strain resulted in a stronger up-regulation in the mRNA level than infection with the $\mathrm{P}_{5}$ strain. However, by 7 dpi, infection with $\mathrm{P}_{5}$ induced a stronger down-regulation than $\mathrm{P}_{115}$ infection. At $14 \mathrm{dpi}$, both virus strains resulted in a similar response, with the majority of mRNAs showing a down-regulation. In contrast, at 21 $\mathrm{dpi}$, the majority of mRNAs were still down-regulated in the $\mathrm{P}_{115}$-infected group, but $\mathrm{P}_{5}$ infection induced upregulation of the mRNA level of several genes.

In comparison with the results obtained using proteomics (summarized in Additional file 6 and Additional file 7), the trends in the mRNA levels of these genes were not completely consistent with the change patterns of their corresponding proteins in 2-DE or 2-DIGE gels. The disparity between the levels of mRNA and their corresponding proteins may occur because posttranscriptional and posttranslational modifications, as well as differential mRNA and protein degradation rates, may also contribute to these discrepancies. Several papers have addressed this question performing parallel proteomic/gene expression studies [23-26].

\section{Protein validation by western blot analysis}

To confirm the dynamic alterations of protein abundance during infection with IBV ck/CH/LDL/97I $\mathrm{P}_{5}$ and ck/CH/LDL/97I $\mathrm{P}_{115}$, three proteins including annexin A2 (ANXA2), annexin A5 (ANXA5), and heat shock protein beta-1 (HSPB1) were selected for western blot analysis. As shown in Figure 6A and 6B, the abundance of HSPB1 was increased in trachea tissues from the $\mathrm{P}_{5^{-}}$ infected group at 4,7 , and $21 \mathrm{dpi}$, relative to the control group. It was also increased in the $\mathrm{P}_{115}$-infected group, relative to the control group. The abundance of Annexin A2 was increased in tracheal tissues from the $\mathrm{P}_{115^{-}}$ infected group at 4 and $7 \mathrm{dpi}$, but decreased in tracheal tissues from the $\mathrm{P}_{5}$-infected group at $7 \mathrm{dpi}$, relative to the control group. In addition, the abundance of annexin $\mathrm{A} 5$ was increased in $\mathrm{P}_{5}$-infected kidney tissues at $7 \mathrm{dpi}$, relative to the control group. These data were in agreement with the results obtained from the 2-DE and 2-DIGE analysis.

\section{Discussion}

Viruses are obligatory intracellular pathogens that rely on the host cell for essentially all steps of their life cycle. Although coronaviruses use host proteins as part of their replication strategies, it has also become clear that the immune, metabolic, stress, cell cycling and
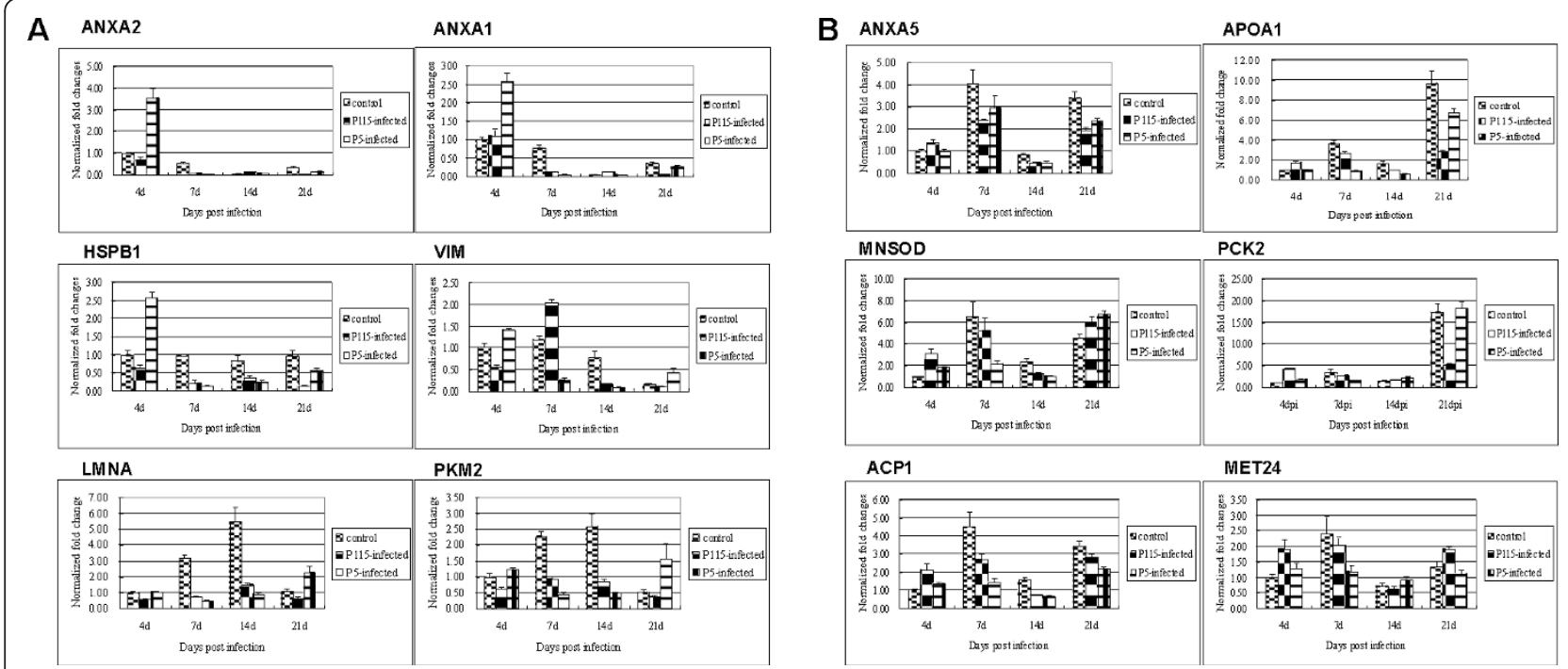

Figure 5 Transcript analysis of the 12 proteins differentially expressed in trachea (A) and kidney (B) of chickens infected with the IBV $\mathbf{c k} / \mathrm{CH} / \mathbf{L D L} / \mathbf{9 7 I} \mathbf{P}_{\mathbf{5}}$ and $\mathbf{c k} / \mathrm{CH} / \mathbf{L D L} / \mathbf{9 7} \mathbf{P}_{\mathbf{1 1 5}}$ strains by real-time RT-PCR. Total RNA extracts were prepared from the trachea and kidney of chickens in the control, $\mathrm{P}_{5}$-infected, and $\mathrm{P}_{115}$-infected group's at all four time points. Data represent means of three biological replicates per group. Error bars indicate standard error. Samples were normalized with the expression of the $18 \mathrm{~S}$ ribosomal RNA gene. For symbols indicating different genes, refer to Tables 1, 2, 3, and 4. 


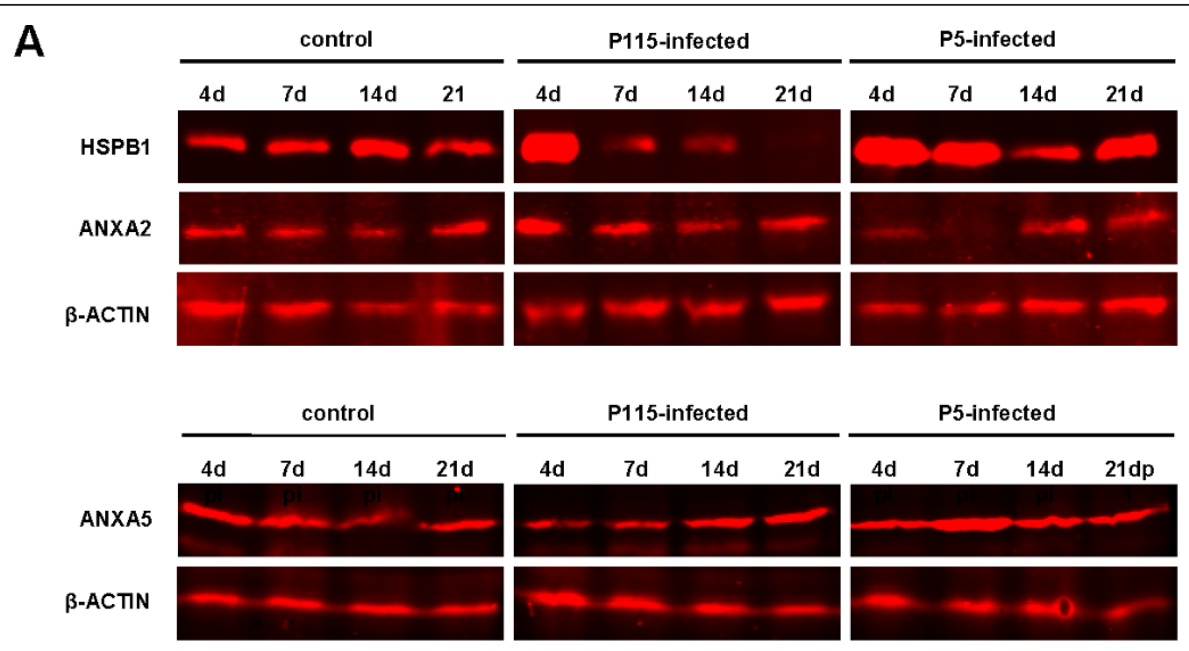

B

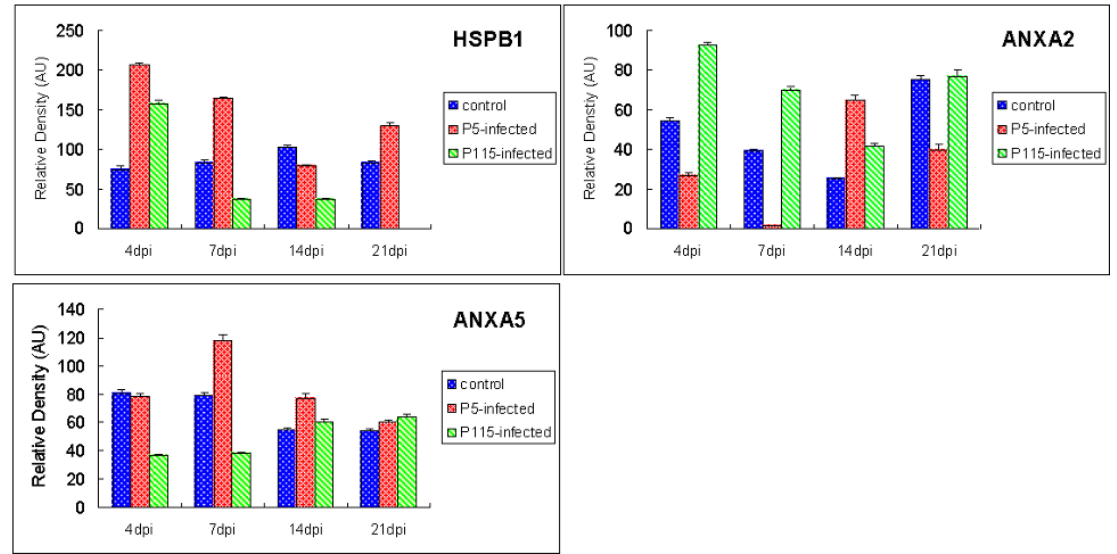

Figure 6 (A) Western blot analysis of heat shock protein beta-1 (HSPB1) and annexin A2 (ANXA2) in trachea tissue, annexin A5 (ANXA5) in kidney tissue of chickens infected with the IBV ck/CH/LDL/97I $P_{5}$ and ck/CH/LDL/97I $P_{115}$ strain. (B) Protein band density was analyzed with the BandScan software. Beta-Actin was used as the internal control. Mean values \pm SE were calculated from three independent samples. AU, arbitrary units.

other pathways are activated by infection. Determination, using genomics and proteomics, of the extent to which virus-host interaction is coronavirus-specific and organ-specific, will be of importance [14,27]. Our previous study on the global profile of host protein alterations in response to IBV infection was focused on an in ovo infection model system [21]. In this study, we applied a comparative proteomics technical platform for the first time to explore the abundance changed protein in trachea and kidney tissues from chicken infected in vivo with the highly virulent $\mathrm{ck} / \mathrm{CH} / \mathrm{LDL} / 97 \mathrm{I} \mathrm{P}_{5}$ strain of IBV and the embryo-passaged, attenuated $\mathrm{ck} / \mathrm{CH} /$ LDL/97I $\mathrm{P}_{115}$ strain of IBV. Some identified proteins are likely to be important in the host response to virus infection, including cytoskeletal proteins, stress response proteins, and anti-oxidative proteins. Interestingly, the abundance of these proteins showed different change patterns with IBV strains differ in virulence, suggesting that some of these differences might be responsible for virulence, and consistent with our previous study which demonstrated the differences in pathology and virulence for these two different viruses [22,28]. These results provide an overview of the proteome profile of the host in response to different virulent IBV infection in vivo.

The cytoskeletal network is a cellular scaffold system whose functions include maintenance of cellular shape, enabling of cellular migration, cell division, intracellular transport, signaling, and membrane organization. Some host cytoskeletal proteins have been reported as differentially altered by virus infection in quantitative proteomic studies [16-18]. Recently, study has revealed that several different cellular proteins involved in cell morphology and the cytoskeleton changed in abundance in IBV infected cells $[19,20]$. IBV infection resulted in a 
number of changes to the nucleolus both in terms of gross morphology and protein content [29]. Our results presented a tendency that the abundance of several cytoskeletal proteins showed increased with the degree of virulence getting strong, which is possibly due to the collapse and dispersal of the cytoskeleton in the IBVinfected cells, as demonstrated by other viruses [30]. Vimentin is a major component of type III intermediate filaments that has been reported to be redistributed in cells around sites of virus replication and assembly during virus infection. For instance, infection with African swine fever virus (ASFV) can lead to the rearrangement of vimentin into a cage surrounding a virus factory, which may prevent movement of viral components into the cytoplasm and concentrate late structural proteins at sites of virus assembly [31]. Specifically, vimentin was observed to be increased in abundance in the cytoplasmic proteome of IBV-infected cells $[19,20]$. In our study, the abundance of vimentin was increased more strongly in the highly virulent $P_{5}$ strain infected group, compared with the attenuated $P_{115}$ strain infected group at $21 \mathrm{dpi}$. Given that vimentin can confer rigidity to domains of the cytoplasm, the vimentin cage may provide a physical scaffold to facilitate the construction of the virus factory. The stronger induction of vimentin could be a result of the large replication capacity of the highly virulent IBV strain. Tropomyosin belongs to the family of actin-binding proteins that serve important functions in microfilament stabilization, regulation of microfilament branching, actin polymerization, and intracellular transport. The abundance of alpha-tropomyosin was found increased in IBV-infected cell $[19,20]$. In our study, the abundance of alpha-tropomyosin was increased much more strongly with highly virulent IBV $\mathrm{ck} / \mathrm{CH} / \mathrm{LDL} / 97 \mathrm{I} \mathrm{P}_{5}$ infection than with the attenuated $\mathrm{P}_{115}$ strain, it is likely that it help to orchestrate virus assembly, release and efficient cell-to-cell spread, also may due to the different virulence between IBV ck/CH/ LDL/97I $\mathrm{P}_{5}$ and $\mathrm{P}_{115}$ strain. In addition, in our previous in ovo infection model [21], the abundance of some cytoskeletal including alpha-tropomyosin was decreased in the IBV-infected embryonic tissues, this difference need to be further investigated.

In both our previous [21] and current study, the abundance of annexin A2 and annexin A5 were found to be changed upon IBV infection. Annexins are a family of conserved proteins characterized by their ability to bind and order charged phospholipids in membranes, often in response to elevated intracellular calcium. These family members are involved specifically in a diverse range of cellular functions both inside the cell and extracellularly [32]. Annexin A2 (ANXA2) can associate with actin filaments and mediates membrane trafficking and membrane-cytoskeletal interactions. It has been identified as an important host factor for several viruses and at different stages of their life cycle. ANXA2 is incorporated into cytomegalovirus and influenza virus particles, promotes the entry of virus, and plays a role in Human immunodeficiency virus -1 (HIV-1) assembly, Bluetongue virus (BTV) release, and hepatitis $C$ virus (HCV) replication [33-40]. Annexin A5 (ANXA5) is involved in various intra- and extracellular processes including signal transduction, anti-inflammatory processes, membrane trafficking, and ion channel activity [41], it also acts to regulate blood coagulation, binding to and shielding exposed phospholipids and masking their pro-thrombotic properties [42]. The expression of ANXA2 and ANXA5 has been found to be altered during other IBV infection system $[19,20]$. In this study, the abundance of ANXA2 showed weaker increase at early stages of infection with the highly virulent IBV ck/CH/ LDL/97I $\mathrm{P}_{5}$ strain than with the attenuated $\mathrm{P}_{115}$ strain. For ANXA5, the level of expression induced at $7 \mathrm{dpi}$ with the highly virulent $P_{5}$ strain of IBV was greater than that induced by the attenuated $\mathrm{P}_{115}$ strain. These trends were also validated by western blot analysis. Whether this difference between $\mathrm{P}_{5}$ and $\mathrm{P}_{115}$ infectioned groups is related with the virulence of IBV or various responses of the host cell deserves further study.

MnSOD is the primary antioxidant enzyme in the mitochondria that catalyzes the conversion of superoxide molecules to hydrogen peroxide and molecular oxygen and therefore forms one of the cell's major defense mechanisms against oxidative stress [43]. Studies have reported that viral infections cause oxidative stress, which is associated with the activation of phagocytes and an increase in the release of reactive oxygen species (ROS) that play a positive modulatory role in immune activation, the inflammatory response, eradication of viral infections and immunity-induced cellular injury [44]. The expression of MnSOD was altered during infection with some viruses, such as porcine reproductive and respiratory syndrome virus, influenza A virus, and SARS-CoV [45-47]. The abundance of the anti-oxidative protein MnSOD was increased much significantly in highly virulent IBV ck/CH/LDL/97I $\mathrm{P}_{5}$ infected group than the attenuated $\mathrm{P}_{115}$ strain infected group. The much amplitude increased production of MnSOD during highly virulent strain infection can affect the host cell pro-/anti-oxidant balance, which probably results in more significant immune activation and a stress response induced by reactive oxygen species. It is important in the eradication of viral infections and immune-induced cellular injury.

When comparing the protein profiles of groups infected with different strains, we found that the abundance of HSPB1, a well-known heat-shock protein, in highly virulent IBV ck/CH/LDL/97I $\mathrm{P}_{5}$ strain infected 
group was significantly higher than the embryo-passaged, attenuated $\mathrm{P}_{115}$ strain at the early stage of infection. Western blot and real-time RT-PCR further confirmed this alteration. HSPB1 has different cytoprotective roles, including acting as a molecular chaperone, maintaining the normal function of cells through interaction with and stabilization of the cytoskeleton, regulation of translational initiation, modulation of inflammation, inhibition of apoptosis, stimulation of innate and adaptive immune responses, and responding to a wide variety of stressful stimuli [48-50]. It is probably involved in all phases of the viral life cycle, including cell entry, virion disassembly, viral genome transcription, replication and morphogenesis. The abundance of HSPB1 was observed to be increased in IBVinfected Vero cells using stable isotope labeling with amino acids in cell culture (SILAC) [20]. IBV infection induces cell cycle arrest at both $\mathrm{S}$ and G2/M phases and caspase-dependent apoptosis at late stages of the viral infection cycle [51-53]. Results presented in our study were probably due to the highly virulent virus triggering a markedly more robust inflammation and stress response. It also suggests that many important, and probably different events in IBV pathogenesis and immunology, such as the stress response, inflammation, and apoptosis, occur early in infection, and that these events may contribute to development of an appropriate immune response and the outcome of viral infection. In our previous study [21], the abundance of HSPB1 was found to be decreased after IBV infection in ovo. This difference in different infection model need to be further examined.

In this study, infection with both the highly virulent strain and the embryo-passaged, attenuated strain of IBV was accompanied by elevation of proteins related to energy metabolism. Viruses are obligate parasites that are completely dependent on their host's cellular metabolism for reproduction. Viral infection has been shown to modulate the levels of numerous host metabolic components in pathways such as glycolysis, the tricarboxylic acid (TCA) cycle, pentose phosphate pathway, and macromolecular biosynthesis in order to redirect valuable resources to their own mass production. Studies have demonstrated that the rate of glycolysis in cells infected by Rous sarcoma virus, feline leukemia virus, and poliomyelitis virus was increased by as much as $370 \%$ [54]. Glycolytic enzymes are involved not only in carbohydrate metabolism and increased ATP production, also take part in the induction of anti-oxidative stress in host cells and contribute to transcription of RNA virus genomes [55]. The abundance of some proteins involved in glycolysis, such as aldose reductase, pyruvate kinase, alpha-enolase, and triosephosphate isomerase was found increased in IBV infected cell $[19,20]$.
Our study also showed that the abundance of some glycolytic enzymes, including phosphoenolpyruvate carboxykinase (PCK1), mitochondrial phosphoenolpyruvate carboxykinase (PCK2), pyruvate kinase, and alpha-enolase, were increased significantly in the early stage of infection with both the highly virulent and the attenuated IBV strain. These findings support the view that IBV infection probably triggers activation of host energy metabolic components via systemic or global mechanisms, to keep up with the energy demands of its own replication.

The post-translational modification (PTM) plays critical roles in cellular regulation. It has been reported that PTM and expression of highly related gene sequences can induce multiple protein spots in animals [56]. An advantage of 2-DE is the monitoring of multiple forms of a protein species, which offers the opportunity to investigate the effects of the virus infection on protein modification. Our study revealed that several proteins were expressed by multiple spots in our study. Although we do not know at present how these multiple spots were generated, some of them were more likely due to post-translational modifications (PTMs), or highly related gene sequences coding isoforms [57].

\section{Conclusion}

In summary, we investigated the proteome profiles of tracheal and kidney tissues from chicken infected with highly virulent IBV ck/CH/LDL/97I $\mathrm{P}_{5}$ and embryo-passaged, attenuated IBV ck/CH/LDL/97I $\mathrm{P}_{115}$. Some proteins involved in cytoskeleton organization, stress response, and anti-oxidative stress, showed different change in abundance with IBV strains differing in virulence. While the roles of some identified alterations could be related to host antiviral response or pathogenic mechanisms, functional significance of other altered proteins remains unclear and needs further investigation. However, our findings provide proteome-related information on a large scale that should be useful in increasing our understanding of the pathogenic and immune mechanisms of IBV infection. In addition, they will also provide reference for similar research into other coronaviruses.

\section{Materials and methods}

\section{Experimental animals and infecting virus strains}

One-day-old White Leghorn specific-pathogen-free (SPF) chickens were obtained from the Laboratory Animal Center, Harbin Veterinary Research Institute, the Chinese Academy of Agricultural Sciences, China. The chickens were maintained in isolators with negative pressure, and food and water were provided ad libitum. This study was approved by the Animal Welfare Committee of Heilongiiang Province, China. 
The highly virulent ck/CH/LDL/97I $\mathrm{P}_{5}$ strain of IBV and attenuated IBV strain $\mathrm{ck} / \mathrm{CH} / \mathrm{LDL} / 97 \mathrm{I} \mathrm{P}_{115}$ were obtained by passaging the IBV ck/CH/LDL/97I strain, which was isolated and identified by our laboratory as described previously [22]. The IBV strains were propagated once in 9- to 11-day-old embryonated SPF chicken eggs for preparation of seed stock. The presence of viral particles in the allantoic fluid of inoculated eggs was confirmed with a negative contrast electronic microscope (JEM-1200, EX) as described previously [22].

\section{Experimental design}

Sixty-six one-day-old SPF White Leghorn chickens were divided randomly into three groups: the $\mathrm{P}_{5}$-infected group, $\mathrm{P}_{115}$-infected group and control group. Twentytwo chickens were allocated to each group and housed in different isolators. Chickens in the $\mathrm{P}_{5}$-infected and $\mathrm{P}_{115}$-infected groups were inoculated with the IBV ck/ $\mathrm{CH} / \mathrm{LDL} / 97 \mathrm{I} \mathrm{P}_{5}$ strain and ck/CH/LDL/97I $\mathrm{P}_{115}$ strain, respectively, by oculo-nasal application at 11 days of age with a dose of $\log 10^{6} \mathrm{EID}_{50}$ per chicken. The chickens in the control group were mock-inoculated in parallel with sterile allantoic fluid.

Blood samples from 10 chickens in each group were collected at 4, 7, 14, and 21 days post inoculation. The sera were collected for enzyme-linked immunosorbent assay (ELISA) testing. Three chickens were selected randomly from each group and killed humanely at 4, 7, 14, and 21 days post inoculation, respectively. Trachea and kidney tissues were separated rapidly and washed with ice-cold PBS buffer, snap-frozen in liquid nitrogen, and kept subsequently at $-80^{\circ} \mathrm{C}$ for $2-\mathrm{DE}$ or 2 -DIGE, realtime RT-PCR, and western blot analysis.

\section{Serum antibody detection}

Serum samples were assayed using a commercial IBV antibody test kit (IDEXX Corporation, Westbrook, Maine, USA) according to the manufacturer's instructions. Each sample was tested in triplicate. Serum-topositive ratios ( $\mathrm{S} / \mathrm{P}$ ratios) were calculated as described previously $[2,58]$. Individual serum titers were calculated from these $\mathrm{S} / \mathrm{P}$ ratios, evaluated as positive or negative, and expressed as $\mathrm{OD}_{650 \mathrm{~nm}}$ values according to the manufacturer's instructions.

\section{Quantitative analysis of IBV in trachea and kidney by real-time RT-PCR}

Viral load of IBV was analyzed using R. M. Jones described methods [59]. Tissue samples were ground and homogenized, $100 \mathrm{mg}$ tissue homogenates were suspended in $500 \mu \mathrm{l}$ phosphate-buffered saline (PBS) containing $100 \mu \mathrm{g}$ penicillin and $100 \mu \mathrm{g}$ streptomycin $/ \mathrm{ml}$, the suspension were freezed thawing three times, then centrifuged at $13,000 \times \mathrm{g}$ at $4^{\circ} \mathrm{C}$ for 5 minutes. RNA was extracted from $200 \mu \mathrm{l}$ tissue supernatant using TRIzol Reagent (Invitrogen) following the manufacturer's instructions. The real-time RT-PCR assay used the following primer and probe sequences: IBVF forward primer CTA TCG CCA GGG AAA TGT C, IBVR reverse primer GCG TCC TAG TGC TGT ACC C, IBV Taq$\operatorname{Man}^{\circledR}$ probe FAM-CCTGGAAACGAACGGTAGACCCT-TAMRA [59]. One-step real-time RT-PCR reactions were performed using One Step PrimeScript ${ }^{\mathbb{R}}$ RT-PCR kit (TaKaRa Biotech Co. Ltd., Dalian) on LightCycler $^{\circledR} 480$ real-time PCR system (Roche) according to the following steps: reverse transcription at $42^{\circ} \mathrm{C}$ for 10 min, denaturation at $95^{\circ} \mathrm{C}$ for $10 \mathrm{~s}$. and 40 cycles with $95^{\circ} \mathrm{C}$ for $5 \mathrm{~s}, 55^{\circ} \mathrm{C}$ for $20 \mathrm{~s}, 72^{\circ} \mathrm{C}$ for $10 \mathrm{~s}$, followed by a $40^{\circ} \mathrm{C}$ for $10 \mathrm{~s}$ cooling step. All of the samples were tested in triplicate in each reaction. The data were analyzed using LightCycler ${ }^{\circledR} 480$ Software Version 1.5.

\section{Preparation of protein samples}

The frozen trachea or kidney tissues were placed in liquid nitrogen and ground thoroughly to a very fine powder. Samples of $100 \mathrm{mg}$ tissue powder were dissolved in $500 \mu \mathrm{l}$ lysing solution containing $7 \mathrm{M}$ urea, 2 $\mathrm{M}$ thiourea, 4\% CHAPS, $40 \mathrm{mM}$ DTT, 2\% IPG buffer pH 3-10, 1\% Nuclease Mix and 1\% Protease Inhibitor Mix (GE Healthcare), then incubated for $2 \mathrm{~h}$ at $4^{\circ} \mathrm{C}$ with vortexing once every $15 \mathrm{~min}$, and centrifuged at 15,000 $\times \mathrm{g}$ for $1 \mathrm{~h}$ at $4^{\circ} \mathrm{C}$. The supernatant was collected and purified with the PlusOne 2D Clean-up kit (GE Healthcare). The concentration of each protein sample was determined with the PlusOne 2D Quant Kit (GE Healthcare). Protein samples were aliquoted and stored at $-80^{\circ}$ C for 2-DE or 2-DIGE analysis.

\section{2-DE analysis of trachea protein samples}

Thirty-six samples of tracheal protein from the three groups ( $\mathrm{P}_{5}$-infected, $\mathrm{P}_{115}$-infected and control) at 4,7 , 14 , and 21 days post-inoculation (dpi) were analyzed by 2-DE using the methods previously described [21]. First, $400 \mu \mathrm{g}$ protein samples were added to rehydration solution (7 M urea, $2 \mathrm{M}$ thiourea, $40 \mathrm{mM}$ DTT, 2\% CHAPS, $0.5 \% \mathrm{pH} 3-10$ or $\mathrm{pH} 4-7$ IPG buffer, and $0.002 \%$ bromophenol blue) to make the final volume up to $250 \mu \mathrm{l}$, following Isoelectric focusing (IEF), the IPG strips were equilibrated and the second dimension separation was performed on $12.5 \%$ SDS-polyacrylamide gels on the SE600 Ruby system (GE Healthcare). Then, the gels were stained with PlusOne Coomassie Blue R-350 (GE Healthcare) and scanned with an ImageScanner III (GE Healthcare). Quantification analyses were performed with Image Master 2D Platinum software v6.0 (GE Healthcare). For image analysis, three independent gels from the $\mathrm{P}_{5}$-infected and $\mathrm{P}_{115}$-infected groups were compared with those from the corresponding control 
group at 4, 7, 14, and 21 dpi respectively. The normalized volume values (vol \%) of matched protein spots were subjected to Student's $t$ test using the SPSS statistical software package version 16.0. The criterion used to define differential expression of spots was that the ratio of the vol \% in the $\mathrm{P}_{5}$-infected group or the $\mathrm{P}_{115^{-}}$ infected group vs. the control group was more than 1.5 $(\mathrm{p}<0.05)$ or less than 0.67 ( $\mathrm{p}<0.05)$. Differentially changed protein spots were excised manually from the gels and subjected to MS analysis.

\section{2-DIGE analysis of kidney protein samples}

The kidney protein samples from each group at 4, 7, 14, and $21 \mathrm{dpi}$ were used for 2-DIGE analysis respectively. The $\mathrm{pH}$ of the protein samples was adjusted to 8.5 and the protein concentration was adjusted to $5 \mu \mathrm{g} / \mu \mathrm{l}$. Equal amounts of protein from each sample were pooled together as the internal standard. The proteins were minimally labeled according to the manufacturer's instructions (CyDye DIGE fluor minimal labeling kit, GE Healthcare). The Cy2 was used to label the pooled internal standard, and Cy3 and Cy5 were used randomly to label samples from the control group, $\mathrm{P}_{5}$-infected group and $\mathrm{P}_{115}$-infected group. To minimize system error and inherent biological variation, the sample multiplexing was also randomized (see Additional file 8) to produce unbiased results. Following the labeling reaction, $50 \mu \mathrm{g}$ of each Cy2, Cy3, and Cy5 labeled sample was mixed, the pooled sample of each gel was adjusted to $450 \mu \mathrm{l}$ with rehydration buffer (7 M urea, $2 \mathrm{M}$ thiourea, 2\%CHAPS, 2\%v/v IPG buffer,130 mM DTT), and loaded subsequently onto $24 \mathrm{~cm}$, linear $\mathrm{pH}$ 3-10 IPG strips (GE Healthcare). Isoelectric focusing (IEF) was performed on an Ettan ${ }^{\mathrm{TM}}$ IPGphor 3 (GE Healthcare) using the following protocol: $30 \mathrm{~V}$ for $12 \mathrm{~h}, 200 \mathrm{~V}$ for $2 \mathrm{~h}, 500 \mathrm{~V}$ for $2 \mathrm{~h}, 1000 \mathrm{~V}$ for $2 \mathrm{~h}, 8000 \mathrm{~V}$ for $3 \mathrm{~h}$, and $8000 \mathrm{~V}$ for $65000 \mathrm{Vh}$. Then, the IPG strips were equilibrated and the second dimension separation was conducted on $12.5 \%$ SDS-polyacrylamide gels using an Ettan $^{\mathrm{TM}}$ DALT six system (GE Healthcare). The CyDyelabeled gels were scanned using a Typhoon 9400 (GE Healthcare). Image analysis was performed using Ettan $^{\mathrm{TM}}$ DeCyder Software version v6.5 (GE Healthcare) as described in the user's manual. The statistical analysis of changes in protein abundance in different gels was performed on the basis of the spot volumes. Protein spots with statistically significant results for the Student's $t$-test $(\mathrm{p}<0.05)$ and Average Ratio more than 1.5 or less than 0.67 were considered to be differentially changed protein spots.

The preparative gels were made with $1200 \mu \mathrm{g}$ of unlabeled proteins ( $400 \mu \mathrm{g}$ from each group). These mixed proteins were loaded and separated under the same conditions as described above. The preparative gels were stained with Coomassie Blue R-350. Each spot of interest, defined on the basis of CyDye images, was matched with a Coomassie Blue R-350 image, then excised manually from the gel and subjected to MS analysis.

\section{MALDI-TOF/TOF MS and database search}

The gel samples were placed in a tube and washed twice

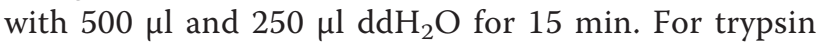
digestion, the gel samples were washed twice with 50 $\mathrm{mM}$ w/v $\mathrm{NH}_{4} \mathrm{HCO}_{3}$ and covered with $10 \mathrm{mg} / \mathrm{ml}$ Porcine Trypsin solution (Promega, Madison, WI, USA) in 50 $\mathrm{mM}$ w/v $\mathrm{NH}_{4} \mathrm{HCO}_{3}$. After incubation overnight at $37^{\circ} \mathrm{C}$, the supernatant was removed into a second tube and 40 $\mu \mathrm{l} 50 \mathrm{mM}$ w/v $\mathrm{NH}_{4} \mathrm{HCO}_{3}$ was added. Gel samples were washed with $40 \mu \mathrm{l}$ of $50 \mathrm{mM}$ w/v $\mathrm{NH}_{4} \mathrm{HCO}_{3}$, the supernatant was collected, and both collected supernatants were combined. The gel was washed with $70 \%$ v/v ACN and dried in a Speed Vac (Vacuum Concentrator, Bachhofer). The peptide mixtures were desalted using ZipTip C-18 RP tips (Millipore, Billerica, MA, USA) which were wetted with $100 \%$ ACN and equilibrated with $0.1 \%$ TFA. Peptide samples, which were redissolved in $10 \mathrm{ml} 0.5 \%$ TFA, were eluted with 50\% ACN/0.1\% TFA and dried in a Speed Vac (Vacuum Concentrator).

The purified peptides were spotted on a MALDI plate and covered with $0.7 \mu \mathrm{l}$ of $2 \mathrm{mg} / \mathrm{ml} \mathrm{3,5-Dimethoxy-4-}$ hydroxycinnamic acid matrix (Sigma) with $10 \mathrm{mM}$ $\mathrm{NH}_{4} \mathrm{H}_{2} \mathrm{PO}_{4}$ in $60 \% \mathrm{ACN}$. All samples were analyzed by MALDI-TOF/TOF MS with a 4700 Proteomics Analyzer (Applied Biosystems, Foster City, CA). Monoisotopic peak masses were acquired in a mass range of 800-4000 $\mathrm{Da}$, with a signal-to-noise ratio $(\mathrm{S} / \mathrm{N})$ of 200 . Five of the most intense ion signals, excluding common trypsin autolysis peaks and matrix ion signals, were selected as precursors for MS/MS acquisition. The peptide mass fingerprint (PMF) combined MS/MS data were submitted to MASCOT version 3.0 (Matrix Science) for identification according to the NCBInr database (release 16/01/2010, 10343571 sequences, 3528215794 residues). The search parameters were set as follows: Gallus, trypsin cleavage (one missed cleavage allowed), carbamidomethylation of cysteine as fixed modification, oxidation of methionine as variable modification, peptide mass tolerance set at $100 \mathrm{ppm}$, fragment tolerance set at 0.8 Da. The criterion for successful identification of a protein was the protein score confidence interval (C.I. \%) $\geq 95 \%$.

\section{Gene ontology (GO) annotation of differentially expressed proteins}

Spot identities were submitted to GORetriever http:// www.agbase.msstate.edu/ to obtain the GO annotations. If no annotation was returned, GOanna was used to retrieve $\mathrm{GO}$ annotations assigned on the basis of sequence similarities. The resulting annotations were 
summarized according to the GOA and whole proteome GOSlim set using GOSlimViewer [60].

\section{Analysis of mRNA levels by real-time RT-PCR}

Specific primers were designed according to the corresponding gene sequences of the MS-identified proteins using Beacon Designer software 7.5 (Primer Biosoft International). Information on the primers is listed in Additional file 9. Total RNA was extracted using TRIzol Reagent (Invitrogen) according to the manufacturer's instructions. Two micrograms of total RNA was reverse transcribed with $200 \mathrm{U}$ M-MLV Reverse Transcriptase (Invitrogen) and $500 \mathrm{ng}$ Oligo $(\mathrm{dT})_{18}$ as the first strand primer in $20 \mu \mathrm{l}$ reaction solution. Real-time RT-PCR was carried out using SYBR ${ }^{\circledR}$ Premix Ex Taq ${ }^{\mathrm{TM}}$ II kit (Takara) on the LightCycler ${ }^{\circledR} 480$ real-time PCR system (Roche) according to the following steps: $30 \mathrm{~s}$ at $95^{\circ} \mathrm{C}$, 40 cycles of denaturation at $95^{\circ} \mathrm{C}$ for $10 \mathrm{~s}$, and annealing and extension at $55^{\circ} \mathrm{C}$ for $45 \mathrm{~s}$. Each sample was amplified in triplicate. Quantitative analysis of the data was performed using the $2^{-\Delta \Delta C t}$ method [61]; samples from the control group at $4 \mathrm{dpi}$ were used as the calibrator (relative expression $=1$ ), and the $18 \mathrm{~S}$ ribosomal RNA gene was used as an internal reference gene.

\section{Western blot analysis}

Samples of tracheal and kidney proteins from the $\mathrm{P}_{5^{-}}$ infected group, $\mathrm{P}_{115}$-infected group, and control group at all four time points were prepared, and the protein concentration was determined as described above. Equivalent amounts of total protein were subjected to $12 \%$ SDS-PAGE and then transferred to a nitrocellulose membrane. After blocking for $1 \mathrm{~h}$ at $37^{\circ} \mathrm{C}$, the membranes were incubated separately with mouse monoclonal antibody to annexin A5 (sc-32321, Santa Cruz Biotechnology, USA), mouse monoclonal antibody to HSPB1 (sc-51956, Santa Cruz Biotechnology, USA), and goat polyclonal antibody to annexin A2 (sc-1924, Santa Cruz Biotechnology, USA) overnight at $4^{\circ} \mathrm{C}$. The membranes were incubated subsequently with IRDye700DX conjugated anti-mouse secondary antibody (610-130121, Rockland, Gilbertsville, PA) for $1 \mathrm{~h}$ at $37^{\circ} \mathrm{C}$, and scanned finally on a LI-COR infrared imaging system using their Odyssey software (Li-Cor Bioscience, Lincoln, NE). $\beta$-actin (sc-47778, Santa Cruz Biotechnology, USA) was used as a reference protein to check equal loading. Triplicate experiments were performed for each sample. Densitometric analysis of protein bands was done by using BandScan software (Glyko).

\section{Additional material}

Additional file 1: Table S1 Serological results post inoculation with IBV ck/CH/LDL/97I $P_{5}$ and ck/CH/LDL/97I $P_{115}$.
Additional file 2: Figure S1 Summary of changes in protein levels over time following infection with IBV ck/CH/LDL/97I $P_{5}$ and $P_{115}$. The $y$ axis shows the number of differentially expressed protein spots; individual spots can be found in Tables 1, 2, 3, and 4.

Additional file 3: This includes the PMF spectrum and confirmed MALDI-TOF-TOF spectrum of differentially expressed protein spots in IBV-infected chick tracheal tissues.

Additional file 4: This includes the PMF spectrum and confirmed MALDI-TOF-TOF spectrum of differentially expressed protein spots in IBV-infected chick kidney tissues.

Additional file 5: Table S2 Biological function of differentially expressed proteins reported in viral infection.

Additional file 6: Table S3 Comparison of the fold changes for protein abundance observed by 2-DE gel analysis and mRNA level obtained by real-time RT-PCR in trachea tissues.

Additional file 7: Table S4 Comparison of the fold changes for protein abundance observed by 2-DIGE gel analysis and mRNA expression obtained by real-time RT-PCR in kidney tissues.

Additional file 8: Table S5 Experiment design of the different fluorescent dye labeling

Additional file 9: Table S6 The primers of Real-time RT-PCR.

\section{Abbreviations}

DPI: Days post infection; ACN: Acetonitrile; CHAPS: 3-[(3-cholamidopropyl) dimethyl-ammonio] -1-propanesulfonate; DTT: Dithiothreitol; IBV: Infectious bronchitis coronavirus; IEF: Isoelectric focusing; IPG: Immobilized pH gradient; MALDI-TOF-TOF/MS: Matrix-assisted laser desorption/ionization time-of-flight tandem mass spectrometry; PMF: Peptide mass fingerprinting; SDS-PAGE: Sodium dodecyl sulfate polyacrylamide gel electrophoresis; SPF: Specific pathogen free; TFA: Trifluoroacetic acid; 2-DE: Two-dimensional gel electrophoresis; 2-DIGE: Two-dimensional fluorescence difference gel electrophoresis.

\section{Acknowledgements}

This work was funded by a grant from the earmarked fund for Modern Agro-industry Technology Research System.

\section{Author details}

'Division of Avian Infectious Diseases, State Key Laboratory of Veterinary Biotechnology, Harbin Veterinary Research Institute, the Chinese Academy of Agricultural Sciences, Harbin 150001, People's Republic of China. ${ }^{2}$ College of Animal Science and Veterinary Medicine, Shenyang Agricultural University, Shenyang 110866, People's Republic of China.

\section{Authors' contributions}

SL designed the study. SL and ZC drafted the manuscript. ZC, ZH, YS, and $X L$ carried out virus infection, serum antibody detection, and quantitative analysis of IBV. ZC, JS and DY carried out the 2-DE experiments, image analysis, excised the protein spots, data analysis and interpretation, confirmed the differential expression by real-time RT-PCR and Western blotting analysis. SL wrote the manuscript. XK revised the manuscript. All authors read and approved the final manuscript.

\section{Competing interests}

The authors declare that they have no competing interests.

Received: 9 December 2011 Accepted: 31 March 2012 Published: 31 March 2012

\section{References}

1. Carstens E: Report from the 40th meeting of the Executive Committee of the International Committee of Taxonomy of Viruses. 2009, 1571-1574.

2. Han Z, Sun C, Yan B, Zhang X, Wang Y, Li C, Zhang Q, Ma Y, Shao Y, Liu Q, et al: A 15-year analysis of molecular epidemiology of avian infectious bronchitis coronavirus in China. Infect Genet Evol 2011, 11:190-200. 
3. Enjuanes L, Almazan F, Sola I, Zuniga S: Biochemical aspects of coronavirus replication and virus-host interaction. Annu Rev Microbiol 2006, 60:211-230.

4. Tang BS, Chan KH, Cheng VC, Woo PC, Lau SK, Lam CC, Chan TL, Wu AK, Hung IF, Leung SY, Yuen KY: Comparative host gene transcription by microarray analysis early after infection of the Huh7 cell line by severe acute respiratory syndrome coronavirus and human coronavirus $229 \mathrm{E}$. $J$ Virol 2005, 79:6180-6193.

5. Dar A, Munir S, Vishwanathan S, Manuja A, Griebel P, Tikoo S, Townsend H, Potter A, Kapur V, Babiuk LA: Transcriptional analysis of avian embryonic tissues following infection with avian infectious bronchitis virus. Virus Res 2005, 110:41-55.

6. Wang X, Rosa AJ, Oliverira HN, Rosa GJ, Guo X, Travnicek M, Girshick T: Transcriptome of local innate and adaptive immunity during early phase of infectious bronchitis viral infection. Viral Immunol 2006, 19:768-774.

7. Ng LF, Hibberd ML, Ooi EE, Tang KF, Neo SY, Tan J, Murthy KR, Vega VB, Chia JM, Liu ET, Ren EC: A human in vitro model system for investigating genome-wide host responses to SARS coronavirus infection. BMC Infect Dis 2004, 4:34

8. Leong WF, Tan HC, Ooi EE, Koh DR, Chow VT: Microarray and real-time RTPCR analyses of differential human gene expression patterns induced by severe acute respiratory syndrome (SARS) coronavirus infection of Vero cells. Microb Infect/Institut Pasteur 2005, 7:248-259.

9. Raaben M, Groot Koerkamp MJ, Rottier PJ, de Haan CA: Mouse hepatitis coronavirus replication induces host translational shutoff and mRNA decay, with concomitant formation of stress granules and processing bodies. Cellular Microbiol 2007, 9:2218-2229.

10. Haq K, Brisbin JT, Thanthrige-Don N, Heidari M, Sharif S: Transcriptome and proteome profiling of host responses to Marek's disease virus in chickens. Vet Immunol Immunopathol 2010, 138:292-302

11. Jiang XS, Tang LY, Dai J, Zhou H, Li SJ, Xia QC, Wu JR, Zeng R: Quantitative analysis of severe acute respiratory syndrome (SARS)-associated coronavirus-infected cells using proteomic approaches: implications for cellular responses to virus infection. Mol Cell Proteomics 2005, 4:902-913.

12. Chen JH, Chang YW, Yao CW, Chiueh TS, Huang SC, Chien KY, Chen A, Chang FY, Wong $\mathrm{CH}$, Chen YJ: Plasma proteome of severe acute respiratory syndrome analyzed by two-dimensional gel electrophoresis and mass spectrometry. Proc Natl Acad Sci USA 2004, 101:17039-17044.

13. Zhang L, Zhang ZP, Zhang XE, Lin FS, Ge F: Quantitative proteomics analysis reveals BAG3 as a potential target to suppress severe acute respiratory syndrome coronavirus replication. J Virol 2010, 84:6050-6059.

14. Vogels MW, van Balkom BW, Kaloyanova DV, Batenburg JJ, Heck AJ, Helms JB, Rottier PJ, de Haan CA: Identification of host factors involved in coronavirus replication by quantitative proteomics analysis. Proteomics 2011, 11:64-80

15. Emmott E, Wise $H$, Loucaides EM, Matthews DA, Digard P, Hiscox JA: Quantitative proteomics using SILAC coupled to LC-MS/MS reveals changes in the nucleolar proteome in influenza A virus-infected cells. J Proteome Res 2010, 9:5335-5345.

16. Munday DC, Emmott E, Surtees R, Lardeau CH, Wu W, Duprex WP, Dove BK, Barr JN, Hiscox JA: Quantitative proteomic analysis of A549 cells infected with human respiratory syncytial virus. Mol Cell Proteomics 2010, 9:2438-2459

17. Coombs KM, Berard A, Xu W, Krokhin O, Meng X, Cortens JP, Kobasa D, Wilkins J, Brown EG: Quantitative proteomic analyses of influenza virusinfected cultured human lung cells. J Virol 2010, 84:10888-10906.

18. van Diepen A, Brand HK, Sama I, Lambooy LH, van den Heuvel LP, van der Well L, Huynen M, Osterhaus AD, Andeweg AC, Hermans PW: Quantitative proteome profiling of respiratory virus-infected lung epithelial cells. $J$ Proteomics 2010, 73:1680-1693.

19. Emmott E, Smith C, Emmett SR, Dove BK, Hiscox JA: Elucidation of the avian nucleolar proteome by quantitative proteomics using SILAC and changes in cells infected with the coronavirus infectious bronchitis virus. Proteomics 2010, 10:3558-3562.

20. Emmott E, Rodgers MA, Macdonald A, McCrory S, Ajuh P, Hiscox JA: Quantitative proteomics using stable isotope labeling with amino acids in cell culture reveals changes in the cytoplasmic, nuclear, and nucleolar proteomes in Vero cells infected with the coronavirus infectious bronchitis virus. Mol Cell Proteomics 2010, 9:1920-1936.
21. Cao Z, Han Z, Shao Y, Geng H, Kong X, Liu S: Proteomic analysis of chicken embryonic trachea and kidney tissues after infection in ovo by avian infectious bronchitis coronavirus. Proteome Science 2011, 9:11.

22. Liu S, Zhang X, Wang Y, Li C, Liu Q, Han Z, Zhang Q, Kong X, Tong G: Evaluation of the protection conferred by commercial vaccines and attenuated heterologous isolates in China against the CK/CH/LDL/97I strain of infectious bronchitis coronavirus. Vet J 2009, 179:130-136.

23. Conrads KA, Yi M, Simpson KA, Lucas DA, Camalier CE, Yu LR, Veenstra TD, Stephens RM, Conrads TP, Beck GR Jr: A combined proteome and microarray investigation of inorganic phosphate-induced pre-osteoblast cells. Mol Cell Proteomics 2005, 4:1284-1296.

24. Kuo CC, Kuo CW, Liang CM, Liang SM: A transcriptomic and proteomic analysis of the effect of CpG-ODN on human THP-1 monocytic leukemia cells. Proteomics 2005, 5:894-906.

25. Scheurer SB, Rybak JN, Rosli C, Neri D, Elia G: Modulation of gene expression by hypoxia in human umbilical cord vein endothelial cells: A transcriptomic and proteomic study. Proteomics 2004, 4:1737-1760.

26. Martin SA, Mohanty BP, Cash P, Houlihan DF, Secombes CJ: Proteome analysis of the Atlantic salmon (Salmo salar) cell line SHK-1 following recombinant IFN-gamma stimulation. Proteomics 2007, 7:2275-2286.

27. Perlman S, Netland J: Coronaviruses post-SARS: update on replication and pathogenesis. Nat Rev Microbiol 2009, 7:439-450.

28. Liu S, Han Z, Chen J, Liu X, Shao Y, Kong X, Tong G, Rong J: S1 gene sequence heterogeneity of a pathogenic infectious bronchitis virus strain and its embryo-passaged, attenuated derivatives. Avian Pathol 2007, 36:231-234

29. Dove BK, You JH, Reed ML, Emmett SR, Brooks G, Hiscox JA: Changes in nucleolar morphology and proteins during infection with the coronavirus infectious bronchitis virus. Cell Microbiol 2006, 8:1147-1157.

30. Radtke K, Dohner K, Sodeik B: Viral interactions with the cytoskeleton: a hitchhiker's guide to the cell. Cell Microbiol 2006, 8:387-400.

31. Stefanovic S, Windsor M, Nagata Kl, Inagaki M, Wileman T: Vimentin rearrangement during African swine fever virus infection involves retrograde transport along microtubules and phosphorylation of vimentin by calcium calmodulin kinase II. J Virol 2005, 79:11766-11775.

32. Hayes MJ, Longbottom RE, Evans MA, Moss SE: Annexinopathies. Subcell Biochem 2007, 45:1-28.

33. Wright JF, Kurosky A, Pryzdial EL, Wasi S: Host cellular annexin II is associated with cytomegalovirus particles isolated from cultured human fibroblasts. J Virol 1995, 69:4784-4791.

34. LeBouder F, Morello E, Rimmelzwaan GF, Bosse F, Pechoux C, Delmas B, Riteau B: Annexin II incorporated into influenza virus particles supports virus replication by converting plasminogen into plasmin. J Virol 2008, 82:6820-6828.

35. Gonzalez-Reyes S, Garcia-Manso A, del Barrio G, Dalton KP, GonzalezMolleda L, Arrojo-Fernandez J, Nicieza I, Parra F: Role of annexin A2 in cellular entry of rabbit vesivirus. J Gen Virol 2009, 90:2724-2730.

36. Raynor CM, Wright JF, Waisman DM, Pryzdial EL: Annexin II enhances cytomegalovirus binding and fusion to phospholipid membranes. Biochemistry 1999, 38:5089-5095.

37. Harrist AV, Ryzhova EV, Harvey T, Gonzalez-Scarano F: Anx2 interacts with HIV-1 Gag at phosphatidylinositol $(4,5)$ bisphosphate-containing lipid rafts and increases viral production in 293T cells. PLoS One 2009, 4:e5020.

38. Ryzhova EV, Vos RM, Albright AV, Harrist AV, Harvey T, Gonzalez-Scarano F: Annexin 2: a novel human immunodeficiency virus type $1 \mathrm{Gag}$ binding protein involved in replication in monocyte-derived macrophages. J Virol 2006, 80:2694-2704.

39. Beaton AR, Rodriguez J, Reddy YK, Roy P: The membrane trafficking protein calpactin forms a complex with bluetongue virus protein NS3 and mediates virus release. Proc Natl Acad Sci USA 2002, 99:13154-13159.

40. Backes P, Quinkert D, Reiss S, Binder M, Zayas M, Rescher U, Gerke V, Bartenschlager $\mathrm{R}$, Lohmann $\mathrm{V}$ : Role of annexin $\mathrm{A} 2$ in the production of infectious hepatitis C virus particles. J Virol 2010, 84:5775-5789.

41. Ravassa S, Bennaghmouch A, Kenis H, Lindhout T, Hackeng T, Narula J, Hofstra L, Reutelingsperger C: Annexin A5 down-regulates surface expression of tissue factor: a novel mechanism of regulating the membrane receptor repertoir. J Biol Chem 2005, 280:6028-6035.

42. Rand $J H, W u X X$, Giesen P: A possible solution to the paradox of the "lupus anticoagulant": antiphospholipid antibodies accelerate thrombin generation by inhibiting annexin-V. Thromb Haemost 1999, 82:1376-1377. 
43. Yesilkaya H, Kadioglu A, Gingles N, Alexander JE, Mitchell TJ, Andrew PW: Role of manganese-containing superoxide dismutase in oxidative stress and virulence of Streptococcus pneumoniae. Infect Immun 2000, 68:2819-2826.

44. Suresh DR, Annam V, Pratibha K, Prasad BV: Total antioxidant capacity-a novel early bio-chemical marker of oxidative stress in HIV infected individuals. J Biomed Sci 2009, 16:61.

45. Zhang H, Guo X, Ge X, Chen Y, Sun Q, Yang H: Changes in the cellular proteins of pulmonary alveolar macrophage infected with porcine reproductive and respiratory syndrome virus by proteomics analysis. J Proteome Res 2009, 8:3091-3097.

46. Lai CC, Jou MJ, Huang SY, Li SW, Wan L, Tsai FJ, Lin CW: Proteomic analysis of up-regulated proteins in human promonocyte cells expressing severe acute respiratory syndrome coronavirus $3 \mathrm{C}$-like protease. Proteomics 2007, 7:1446-1460.

47. Vester D, Rapp E, Kluge S, Genzel Y, Reichl U: Virus-host cell interactions in vaccine production cell lines infected with different human influenza $A$ virus variants: a proteomic approach. J Proteomics 2010, 73:1656-1669.

48. Samali A, Robertson JD, Peterson E, Manero F, van Zeijl L, Paul C, Cotgreave IA, Arrigo AP, Orrenius S: Hsp27 protects mitochondria of thermotolerant cells against apoptotic stimuli. Cell Stress Chaperones 2001, 6:49-58.

49. Concannon CG, Gorman AM, Samali A: On the role of Hsp27 in regulating apoptosis. Apoptosis 2003, 8:61-70.

50. Ferns G, Shams S, Shafi S: Heat shock protein 27: its potential role in vascular disease. Int J Exp Pathol 2006, 87:253-274.

51. Liu C, Xu HY, Liu DX: Induction of Caspase-Dependent Apoptosis in Cultured Cells by the Avian Coronavirus Infectious Bronchitis Virus. J Virol 2001, 75:6402-6409.

52. Li F: Cell cycle arrest and apoptosis induced by the coronavirus infectious bronchitis virus in the absence of p53. Virology 2007, 365:435-445.

53. Dove B, Brooks G, Bicknell K, Wurm T, Hiscox JA: Cell Cycle Perturbations Induced by Infection with the Coronavirus Infectious Bronchitis Virus and Their Effect on Virus Replication. J Virol 2006, 80:4147-4156.

54. Maynard ND, Gutschow MV, Birch EW, Covert MW: The virus as metabolic engineer. Biotechnol J 2010, 5:686-694.

55. Kim JW, Dang CV: Multifaceted roles of glycolytic enzymes. Trends Biochem Sci 2005, 30:142-150

56. Tabuse $Y$, Nabetani T, Tsugita A: Proteomic analysis of protein expression profiles during Caenorhabditis elegans development using twodimensional difference gel electrophoresis. Proteomics 2005, 5:2876-2891.

57. Gorg A, Weiss W, Dunn MJ: Current two-dimensional electrophoresis technology for proteomics. Proteomics 2004, 4:3665-3685.

58. Liu S, Zhang X, Gong L, Yan B, Li C, Han Z, Shao Y, Li H, Kong X: Altered pathogenicity, immunogenicity, tissue tropism and 3 '-7 kb region sequence of an avian infectious bronchitis coronavirus strain after serial passage in embryos. Vaccine 2009, 27:4630-4640.

59. Jones RM, Ellis RJ, Cox WJ, Errington J, Fuller C, Irvine RM, Wakeley PR: Development and Validation of RT-PCR Tests for the Detection and S1 Genotyping of Infectious Bronchitis Virus and Other Closely Related Gammacoronaviruses Within Clinical Samples. Transbound Emerg Dis 2011, 58:411-420.

60. McCarthy FM, Bridges SM, Wang N, Magee GB, Williams WP, Luthe DS, Burgess SC: AgBase: a unified resource for functional analysis in agriculture. Nucleic Acids Res 2007, 35:D599-D603.

61. Livak KJ, Schmittgen TD: Analysis of relative gene expression data using real-time quantitative PCR and the 2(-Delta Delta C(T)) Method. Methods 2001, 25:402-408.

doi:10.1186/1477-5956-10-24

Cite this article as: Cao et al:: Proteomics analysis of differentially expressed proteins in chicken trachea and kidney after infection with the highly virulent and attenuated coronavirus infectious bronchitis virus in vivo. Proteome Science 2012 10:24.

\section{Submit your next manuscript to BioMed Central and take full advantage of:}

- Convenient online submission

- Thorough peer review

- No space constraints or color figure charges

- Immediate publication on acceptance

- Inclusion in PubMed, CAS, Scopus and Google Scholar

- Research which is freely available for redistribution

Submit your manuscript at www.biomedcentral.com/submit 